\title{
Fusing Multi-Attribute Decision Models for Decision Making to Achieve Optimal Product Design
}

\author{
Olayinka Mohammed Olabanji ${ }^{1}$, Khumbulani Mpofu ${ }^{1}$
}

\begin{abstract}
Manufacturers need to select the best design from alternative design concepts in order to meet up with the demand of customers and have a larger share of the competitive market that is flooded with multifarious designs. Evaluation of conceptual design alternatives can be modelled as a Multi-Criteria Decision Making (MCDM) process because it includes conflicting design features with different sub features. Hybridization of Multi Attribute Decision Making (MADM) models has been applied in various field of management, science and engineering in order to have a robust decision-making process but the extension of these hybridized MADM models to decision making in engineering design still requires attention. In this article, an integrated MADM model comprising of Fuzzy Analytic Hierarchy Process (FAHP), Fuzzy Pugh Matrix and Fuzzy VIKOR was developed and applied to evaluate conceptual designs of liquid spraying machine. The fuzzy AHP was used to determine weights of the design features and sub features by virtue of its fuzzified comparison matrix and synthetic extent evaluation. The fuzzy Pugh matrix provides a methodical structure for determining performance using all the design alternatives as basis and obtaining aggregates for the designs using the weights of the sub features. The fuzzy VIKOR generates the decision matrix from the aggregates of the fuzzified Pugh matrices and determine the best design concept from the defuzzified performance index. At the end, the optimal design concept is determined for the liquid spraying machine.
\end{abstract}

Keywords: Hybridized Multi-Attribute Decision-making, Fuzzy AHP, Fuzzified Pugh Matrix, Fuzzy VIKOR, Optimal conceptual design.

\section{Introduction}

The desire of manufacturers to have a sustainable product with prolonged and useful life cycle can be achieved through a comprehensive and systematic decision process in the conceptual design phase [1,2]. Selection of best design concept from an alternative set of designs is an important stage in engineering design process that requires attention because the performance of the final design throughout its life cycle depends on some features that may have been considered during the decision process [3, 4]. In practice, design concepts are developed based on user's requirements and underlying design principles. However, during

\footnotetext{
${ }^{1}$ Tshwane University of Technology Pretoria West, South Africa
} 
the concept design process, the designers are constrained to add design features that will satisfy the requirements or demands of the end users $[5,6]$. Since the demands of end users are multifarious, hence there is no particular design concept that tends to satisfy all the expected design features. In view of this, design engineers are left with no option than to have different design concepts. Since it easier for the managerial team to harness all the required information that is obtainable form the market, then the next task of the design engineer is to analyze the design requirements and allot same to different design features [7, 8]. To further simplify the design process, the design engineers usually assign similar end user's requirements to various sub features that can be traced to a particular design feature. In essence, the design engineers have alternative design concepts with numerous sub features that have been categorized under identified design features $[9,10]$. At this stage the task of choosing the best design concept requires a detailed evaluation of the design features and their sub features because this dictates to the manufacturer the right product to choose in order to have a share of the competitive market flooded with diverse designs [11-13]. It is worthwhile to know at this stage that these design features and sub features have various units and dimensions which makes it difficult to apportion crisp values to them in the decision process. Hence, there is a need to employ a robust decision process in order to avoid any form of ambiguity in the process of selecting the best design. Considering the fact that the manufacturer wants to provide a product that will capture a reasonable share of the market, it becomes imperative to carry out a decision-making process at the conceptual phase of the design. This leads to modelling the decision process as a multi criteria decision model in order to achieve the selection of the optimal design concept.

In the past, when the goal of the manufacturer is achieving mass production, selection of best design concept has been done based on the decisions of design experts by selecting a design concept having the required and cogent design features [14, 15]. However, in recent times when the goal has shifted from mass production to personalized and/or mass customization of products, selection of best design concept of products requires a systematic process that involves the use of extensive decision tools [16, 17]. Decision making in engineering design can be modelled as a Multi-Criteria Decision Analysis (MCDA) where all the design features and sub features can be apportioned weights and the relative importance of the design features in the design alternatives are evaluated using appropriate MCDA tools [2, 18, 19]. Basically, MCDA can be broadly classified into Multi-Attribute Decision making (MADM) and Multi-Objective Decision Making (MODM) [5, 20, 21]. The MADM deals with the challenges of making a choice from a set of alternatives within a discrete solution space. It utilizes approaches such as Analytic Hierarchy Process (AHP), Weighted Sum Model (WSM), Weighted Average model (WA), Analytic Network Process (ANP), VIseKriterijumska Optimizacija I Kompromisno Resenje (VIKOR) and Elimination and Choice Translating Reality (ELECTRE) among others [4]. Considering the ELECTRE model, developed by Bernard Roy [22], it is an outranking method applied to different difficulties encountered within a specific problem. There are several versions of the model as a result of deviation in decision problem from choice of identifying a single alternative to development of ranking sets of alternatives considering the imprecision in performances of the alternatives relative to several criteria [23]. The MODM comes to play when there are no discrete sets of explicitly defined alternatives. MODM provides search for an infinite set solution in a continuous space and it usually emerges at two stages which are implementation of higher-level strategic decisions at a more detailed operational level and generation of explicit set of alternatives for more detailed evaluation before a final decision is reached. 
Examples of methods applied in MODM are linear programming approaches, Technique for Order Preference by Similarity to Ideal Solution (TOPSIS) and Goal Programming (GP) [2426].

In recent times, attempts have been made to improve decision making by hybridizing MADM models to solve real life problems. Some of these applications includes supplier selection [27], auxiliary systems of ship main engines [28], green supply chain implementation in the textile industry [29], gas turbine component selection [30], healthcare decision making [31], combination of materials selection [32] and Steam boilers [33]. However, extending the application of hybridized models to ranking of design concepts is still a decision task of interest because only few article has addressed such approach $[34,35]$. The choice of models to select for integration depends on the computational procedure of the models and nature of the features used in the decision process. Best results can be obtained by harnessing the advantages of the MADM models to be hybridized. In essence, the aim of this article is to investigate the hybridization of MADM models to make decision on the best design concept considering several conceptual design alternatives. The investigation will address the challenges of determining optimal design concept from a set of alternatives by providing a repeatable method that can be applied for subsequent designs. This implies that, research questions regarding which robust decision model can be employed for assessing alternative conceptual designs in order to identify optimal design concept will be addressed in as much as the design engineer has identified the design features and sub features required for characterizing the optimal or best design.

Further, on the aspect of repeatability of the hybridized model, the study will provide a detailed framework that represents the procedure for application of the model in order to ensure that it can be applied by other design engineer in making decision for other products or design alternatives. Although this depends on establishment of design features and sub features of subsequent design that will be used with the hybridized model. The choice of design features and sub features to be applied in the decision process has always been a challenge in the modelling of best design concept selection as a multi criteria decision model. The generic design features which is usually embedded in design for $\mathrm{X}$ principles finds usefulness in the decision process but it is usually faced with the challenges of addressing some peculiar features and requirements of the design, particularly considering features that has to do with functionality or expected performance of the design. In essence, the example that will be proposed in this article will have design features which are peculiar to the design under consideration which can be added to the generic design features in order to have a robust decision process.

To this end, this article proposes an integration of Fuzzy Analytic Hierarchy Process (FAHP), fuzzified Pugh matrix (FPM) and fuzzy VIKOR (FVIKOR) for evaluating design concepts using a trapezoidal fuzzy number. Although AHP, Pugh matrix and VIKOR are methods that can be used separately for decision making but hybridizing these methods will harness their computational strength. For instance, the AHP is good in the aspect of pairwise comparison which usually provides priority for alternatives or criteria under comparison. The Pugh matrix is a good decision tool to consider when it is required to compare all alternatives relative to each other and also considering the weights of the design features or sub features. Also, the VIKOR method is known for its computational integrity in terms of the worst and best values and separation measures in order to arrive at a performance index for the alternatives. Hence, the main reason for hybridizing these methods in this article is to harvest their computational strengths in order to have a robust decision-making process. The primary 
reason for using trapezoidal fuzzy numbers $(\mathrm{TrFN})$ can be stated as its intuitive and efficient computational representation. They are appropriate for quantifying the vague information about most decision problems, particularly in design analysis because the design features cannot be quantified with the same dimensions or units. The novelty of this article is integrating the computational strength of Fuzzy AHP in terms of Fuzzy Synthetic Extent (FSE) from fuzzified pairwise comparison matrix to obtain weights for the design features and sub features and then using these weights to aggregate the Fuzzified Pugh (FPUGH) matrices developed using all the alternatives as basis. The obtained aggregates are used to generate the decision matrix using the computational strength of Fuzzy VIKOR (FVIKOR) in terms of the distances of the design alternatives from fuzzy best and worst values, separation measures and performance index computations.

\section{Methodology}

A framework for the hybridized model is presented in Figure 1. This framework is necessary for highlighting the procedure required for applying the hybridized model to other product design. In the framework, stages involving each of the hybridized MADM models are represented in coloured textbox in order simplify the application process. To further simplify the repeatability of the hybridized model for other designs, attempts have been made to include the equation numbers of the mathematical models that will applied at each stage of the process. To begin with, Fuzzified Pairwise Comparison Matrices (FPCM) are needed for the design features and their various sub features. These matrices are obtained from allocation of TrFN by design experts. The aggregates from the comparison matrices of the sub features that are obtained from Fuzzy Synthetic Extent (FSE) values are required as weights for the fuzzified Pugh matrices. These Pugh matrices are developed for all design features using the design concepts as basis. The aggregated TrFN from the Pugh matrices of the design features formulates elements of the fuzzy decision matrix. Also, the decision matrix is weighted by the aggregate of the comparison matrix of the design features. The fuzzy best and worst values are obtained from the decision matrix. The separation measures and performance index of the design concepts are obtained and defuzzified in order to achieve ranking of the design concepts. The linguistic terms and the distribution for the trapezoidal fuzzy number is presented in Table 1.

Table 1. Trapezoidal Fuzzy Numbers and Linguistic terms adopted for FAHP and FPUGH

\begin{tabular}{|c|c|c|}
\hline \multicolumn{3}{|c|}{ Fuzzy AHP } \\
\hline $\begin{array}{l}\text { Linguistic Terms for Relative } \\
\text { Significance of design features } \\
\text { and sub features in the Design }\end{array}$ & \begin{tabular}{|c|} 
Trapezoidal Fuzzy \\
Scale Membership \\
Function
\end{tabular} & $\begin{array}{l}\text { Crisp Value } \\
\text { of Ranking/ } \\
\text { Rating }\end{array}$ \\
\hline \begin{tabular}{|l|} 
Equally Important \\
\end{tabular} & $\begin{array}{llll}1 & 1 & 1 & 1 \\
\end{array}$ & 1 \\
\hline Weakly Important & $\begin{array}{llll}1 & 3 / 2 & 2 & 5 / 2\end{array}$ & 2 \\
\hline Essentially Important & $\begin{array}{llll}7 / 4 & 9 / 4 & 11 / 4 & 13 / 4\end{array}$ & 3 \\
\hline Highly Important & $\begin{array}{llll}5 / 2 & 3 & 7 / 2 & 4\end{array}$ & 4 \\
\hline Very highly Important & $\begin{array}{|llll|}13 / 4 & 15 / 4 & 17 / 4 & 19 / 4 \\
\end{array}$ & 5 \\
\hline \multicolumn{3}{|c|}{ Fuzzy PUGH } \\
\hline
\end{tabular}




\begin{tabular}{|c|c|c|}
\hline \multicolumn{2}{|c|}{$\begin{array}{l}\text { Linguistic Terms for comparing Design } \\
\text { concepts considering the sub features } \\
\text { Trapezoidal Fuzzy Scale Membership Function }\end{array}$} & $\begin{array}{l}\text { Crisp Value } \\
\text { of Ranking/ } \\
\text { Rating }\end{array}$ \\
\hline Much Better & \begin{tabular}{|llll}
$13 / 4$ & $15 / 4$ & $17 / 4$ & $19 / 4$
\end{tabular} & 1 \\
\hline Better & $\begin{array}{|llll|}5 / 2 & 3 & 7 / 2 & 4 \\
\end{array}$ & 2 \\
\hline Same & $\begin{array}{llll}1 & 1 & 1 & 1\end{array}$ & 3 \\
\hline Worse & $\begin{array}{llll}7 / 4 & 9 / 4 & 11 / 4 & 13 / 4\end{array}$ & 4 \\
\hline Much Worse & $\begin{array}{llll}1 & 3 / 2 & 2 & 5 / 2\end{array}$ & 5 \\
\hline
\end{tabular}

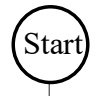

Establish the importance of the design features as required in the optimal design. Also establish the importance of the sub

Identify all requirements and design features that is expected to be available in the optimal design. Also identify all sub features associated with each design features considering their relative importance in the

Develop FPCM for the design features considering their relative importance and contribution to performance of the optimal design. (See equation 2)

Determine the fuzzy synthetic extent evaluation numbers for each design feature from the FPCM for the design features. (See equations $4,6$ and 8$)$

features of individual design feature as needed in the optimal design.

scale of linguistic terms with respective $\operatorname{TrFN}$. The linguistic terms allotted to different or same fuzzy numbers for various comparison process must be specified for clarity. (See Table 1)

Develop FPCM for the sub features considering their contributions to the relative importance of the design feature in the optimal design. Also, consider the relative importance of the sub features as they affect the overall performance of the optimal design. (See equation 3)

Develop Pugh matrices for the sub features considering all alternative design concept as basis for comparison in each case. The weights of the Pugh matrices will be the FSE values of

the sub features. Obtain the aggregate by considering the weights of the sub features (See equations 12 and 13)

Develop a fuzzified decision matrix

from the aggregates of the design concepts from each of the design features (See equation 14)

Determine the performance Index VIKOR from the separation measures. Defuzzify the values of the performance index and rank the design concepts based on the Defuzzified values (See equations 19, 20 and 21)

Determine the fuzzy synthetic extent evaluation numbers for each sub feature from the FPCM for the sub features. (See equations 5, 7 and 9)

Obtain the fuzzy best and worst values from the fuzzified decision matrix. (See equations 15 and 16)

Determine the separation measures of the design concepts from the fuzzy best and worst values and the weights of the design features. (See equations 17 and 18)

Figure 1. Framework for Hybridized Model 


\subsection{Fuzzy AHP}

In order to simplify the analysis, consider $n$ number of design concepts $\left(D_{C n}\right)$ which represents alternatives from which an optimal design will be chosen using $m$ number of design features $\left(D_{F m}\right)$ that are characterized by $k$ number of sub features $\left(S_{F k}\right)$. In order to quantify the relative importance of the design features and sub features in the optimal design, it is necessary to assign trapezoidal fuzzy numbers $\left(A_{i}\right)$ to the elements of the pairwise comparison matrices using linguistic terms presented in Table 1. The membership function ' $\mu_{A}(y)$ ' of the trapezoidal fuzzy number (TrFN) $A=\{a, b, c, d\}$ can be expressed as; [36, 37]

$$
\mu_{A}(y)= \begin{cases}\frac{y-a}{b-a} & y \in[a, b] \\ 1 & y \in[b, c] \\ \frac{d-y}{d-c} & y \in[c, d] \\ 0 & \text { Otherwise }\end{cases}
$$

Where $a \leq b \leq c \leq d$. Judgement matrices of the form $\tilde{B}=\left\{\tilde{b}_{g i}^{j}\right\}$ can be developed for pairwise comparison matrices of the design features and sub features. Where $j$ and $i$ represents columns and rows respectively. Since there are $m$ number of design features with $k$ number of different sub-features it follows that the element in the rows of the judgement matrices for the design features and sub features will be represented with $m$ and $k$ respectively. In essence, judgement matrix for the design features can be expressed as shown in equation 2. Also, since there are various sub features under each of the design features, judgement matrices of the sub features can also be described as presented in equation 3 [38, 39].

$$
\tilde{D}_{F}=\left[\begin{array}{cccc}
\tilde{d}_{f 1}^{1} & \tilde{d}_{f 1}^{2} & \ldots \ldots \ldots . . \tilde{d}_{f 1}^{q} \\
\tilde{d}_{f 2}^{1} & \tilde{d}_{f 2}^{2} & \ldots \ldots \ldots . . \tilde{d}_{f 2}^{q} \\
\vdots & \vdots & \vdots \\
\tilde{d}_{f m}^{1} & \tilde{d}_{f m}^{1} & \ldots \ldots \ldots . . \tilde{d}_{f m}^{q}
\end{array}\right]
$$

Since $j$ and $i$ represents columns and rows respectively then it follows that $i=1,2,3 \ldots m$; $j=1,2,3 \ldots q$ such that $\tilde{d}_{f 1}^{q}=\left[\begin{array}{llll}1 & 1 & 1 & 1\end{array}\right]$ when $i=j$. 


$$
\tilde{S}_{\left.F_{k}\right|_{m}}=\left[\begin{array}{cccc}
\tilde{s}_{f 1}^{1} & \tilde{s}_{f 1}^{2} & \ldots \ldots \ldots . . \tilde{s}_{f 1}^{p} \\
\tilde{s}_{f 2}^{1} & \tilde{s}_{f 2}^{2} & \ldots \ldots \ldots \tilde{s}_{f 2}^{p} \\
\vdots & \vdots & \vdots \\
\tilde{s}_{f k}^{1} & \tilde{s}_{f k}^{2} & \ldots \ldots \ldots . . \tilde{s}_{f k}^{p}
\end{array}\right]
$$

Similarly, since $j$ and $i$ represents columns and rows respectively then it follows that $i=1$, $2,3 \ldots k ; j=1,2,3 \ldots p$ such that $\tilde{s}_{f k}^{p}=\left[\begin{array}{llll}1 & 1 & 1 & 1\end{array}\right]$ when $i=j$. Where $\left.\tilde{S}_{F_{k}}\right|_{m}$ represents $k$ set of sub features corresponding to design feature $m$ and $\tilde{s}_{f k}^{j}$ is the $\operatorname{TrFN}$ for $k^{\text {th }}$ sub feature corresponding to $j^{\text {th }}$ column. Similarly, from equation $2, \tilde{d}_{f m}^{j}$ is the $\operatorname{TrFN}$ for $m^{\text {th }}$ design feature corresponding to $j^{\text {th }}$ column. The fuzzy synthetic extent $\left(F_{s e}\right)$ will be obtained for all the pairwise comparison matrices that have been developed for all the design features and the sub features. In essence, the weights of the relative importance of the design features ( $D_{F m}^{w}$ ) and sub features $\left(S_{F_{k}}^{w}\right)$ will be obtained from the value of the fuzzy synthetic extent which can be defined for the design features " $\left[F_{s e}\right]_{\tilde{D}_{F}}$ " and sub features " $\left[F_{s e}\right]_{\tilde{S}_{F k}}$ " as presented in equations 4 and 5. This implies that the $\left(F_{s e}\right)$ for the design features is obtainable from equation 4 following the pairwise comparison matrix in equation 2 and the $\left(F_{s e}\right)$ for the sub features is obtainable from equation 5 following the pairwise comparison matrix in equation $3[40,41]$;

$$
\begin{gathered}
D_{F m}^{w}=\left[F_{s e}\right]_{\tilde{D}_{F}}=\sum_{j=1}^{q} d_{f m}^{j} \otimes\left[\sum_{i=1}^{m} \sum_{j=1}^{q} d_{f m}^{j}\right]^{-1} \\
S_{F_{k}}^{w}=\left[F_{s e}\right]_{\tilde{S}_{F k}}=\sum_{j=1}^{p} s_{f k}^{j} \otimes\left[\sum_{i=1}^{k} \sum_{j=1}^{p} s_{f k}^{j}\right]^{-1}
\end{gathered}
$$

Considering the fact that equations 4 and 5 are crucial for determination of weights for the design features and sub features, it is necessary to provide an example of their application. In order to achieve this, consider substituting the membership function of the TrFN in equation 1 into equations 2 and 3, this will further analyze the elements of the pairwise comparison matrices of the design features and sub features into simpler form as presented in equations 6 and 7 respectively. This implies that equations 4 and 5 will be applied to equations 6 and 7 respectively. 


$$
\tilde{D}_{F}=\left[\begin{array}{ccc}
a_{11}, b_{11}, c_{11}, d_{11} & a_{21}, b_{21}, c_{21}, d_{21} & \ldots \ldots \ldots a_{q 1}, b_{q 1}, c_{q 1}, d_{q 1} \\
a_{12}, b_{12}, c_{12}, d_{12} & a_{22}, b_{22}, c_{22}, d_{22} & \ldots \ldots \ldots a_{q 2}, b_{q 2}, c_{q 2}, d_{q 2} \\
\vdots & \vdots & \vdots \\
a_{1 m}, b_{1 m}, c_{1 m}, d_{1 m} & a_{2 m}, b_{2 m}, c_{2 m}, d_{2 m} & \ldots \ldots \ldots a_{q m}, b_{q m}, c_{q m}, d_{q m}
\end{array}\right]
$$

Where;

$a_{11}, b_{11}, c_{11}, d_{11}=a_{22}, b_{22}, c_{22}, d_{22}=a_{q m}, b_{q m}, c_{q m}, d_{q m}=[1,1,1,1] \forall q=m$

$\left.\tilde{S}_{F_{k}}\right|_{m}=\left[\begin{array}{ccc}a_{11}, b_{11}, c_{11}, d_{11} & a_{21}, b_{21}, c_{21}, d_{21} & \ldots \ldots \ldots a_{p 1}, b_{p 1}, c_{p 1}, d_{p 1} \\ a_{12}, b_{12}, c_{12}, d_{12} & a_{22}, b_{22}, c_{22}, d_{22} & \ldots \ldots \ldots a_{p 2}, b_{p 2}, c_{p 2}, d_{p 2} \\ \vdots & \vdots & \vdots \\ a_{1 k}, b_{1 k}, c_{1 k}, d_{1 k} & a_{2 k}, b_{2 k}, c_{2 k}, d_{2 k} & \ldots \ldots \ldots a_{p k}, b_{p k}, c_{p k}, d_{p k}\end{array}\right]$

Where

$a_{11}, b_{11}, c_{11}, d_{11}=a_{22}, b_{22}, c_{22}, d_{22}=a_{p k}, b_{p k}, c_{p k}, d_{p k}=[1,1,1,1] \forall p=k$

Applying equation 4 to equation 6 we have;

$$
\begin{gathered}
D_{F_{1}}^{w}=\left[a_{11}+a_{21}+\ldots a_{q 1}\right],\left[\begin{array}{l}
b_{11}+b_{21}+\ldots b_{q 1}
\end{array}\right],\left[c_{11}+c_{21}+\ldots c_{q 1}\right],\left[d_{11}+d_{21}+\ldots d_{q 1}\right] \otimes \\
{\left[\left[\begin{array}{l}
a_{11}+a_{12}+\ldots a_{1 m}+ \\
a_{21}+a_{22}+\ldots a_{2 m}+ \\
a_{q 1}+a_{q 2}+\ldots a_{q m}
\end{array}\right],\left[\begin{array}{l}
b_{11}+b_{12}+\ldots b_{1 m}+ \\
b_{21}+b_{22}+\ldots b_{2 m}+ \\
b_{q 1}+b_{q 2}+\ldots b_{q m}
\end{array}\right],\left[\begin{array}{l}
c_{11}+c_{12}+\ldots c_{1 m}+ \\
c_{21}+c_{22}+\ldots c_{2 m}+ \\
c_{q 1}+c_{q 2}+\ldots c_{q m}
\end{array}\right],\left[\begin{array}{l}
d_{11}+d_{12}+\ldots d_{1 m}+ \\
d_{21}+d_{22}+\ldots d_{2 m}+ \\
d_{q 1}+d_{q 2}+\ldots d_{q m}
\end{array}\right]\right]^{-1}}
\end{gathered}
$$

In the same way, applying equation 5 to equation 7 will yield;

$$
\begin{gathered}
S_{F_{1}}^{w}=\left[a_{11}+a_{21}+\ldots a_{p 1}\right],\left[b_{11}+b_{21}+\ldots b_{p 1}\right],\left[c_{11}+c_{21}+\ldots c_{p 1}\right],\left[d_{11}+d_{21}+\ldots d_{p 1}\right] \otimes \\
{\left[\left[\begin{array}{l}
a_{11}+a_{12}+\ldots a_{1 k}+ \\
a_{21}+a_{22}+\ldots a_{2 k}+ \\
a_{p 1}+a_{p 2}+\ldots a_{p k}
\end{array}\right],\left[\begin{array}{l}
b_{11}+b_{12}+\ldots b_{1 k}+ \\
b_{21}+b_{22}+\ldots b_{2 k}+ \\
b_{p 1}+b_{p 2}+\ldots b_{p k}
\end{array}\right],\left[\begin{array}{l}
c_{11}+c_{12}+\ldots c_{1 k}+ \\
c_{21}+c_{22}+\ldots c_{2 k}+ \\
c_{p 1}+c_{p 2}+\ldots c_{p k}
\end{array}\right],\left[\begin{array}{l}
d_{11}+d_{12}+\ldots d_{1 k}+ \\
d_{21}+d_{22}+\ldots d_{2 k}+ \\
d_{p 1}+d_{p 2}+\ldots d_{p k}
\end{array}\right]\right]^{-1}}
\end{gathered}
$$

In essence, equations 8 and 9 will provide the fuzzy synthetic extents for first design feature and sub features respectively. Following the same pattern, the fuzzy synthetic extents for the second design feature or the second sub feature a design feature can also be obtained as presented in equations 10 and 11 respectively. 


$$
\begin{aligned}
& D_{F_{2}}^{w}=\left[a_{12}+a_{22}+\ldots a_{q 2}\right],\left[b_{12}+b_{22}+\ldots b_{q 2}\right],\left[c_{12}+c_{22}+\ldots c_{q 2}\right],\left[d_{12}+d_{22}+\ldots d_{q 2}\right] \otimes \\
& {\left[\left[\begin{array}{l}
a_{11}+a_{12}+\ldots a_{1 m}+ \\
a_{21}+a_{22}+\ldots a_{2 m}+ \\
a_{q 1}+a_{q 2}+\ldots a_{q m}
\end{array}\right],\left[\begin{array}{l}
b_{11}+b_{12}+\ldots b_{1 m}+ \\
b_{21}+b_{22}+\ldots b_{2 m}+ \\
b_{q 1}+b_{q 2}+\ldots b_{q m}
\end{array}\right],\left[\begin{array}{l}
c_{11}+c_{12}+\ldots c_{1 m}+ \\
c_{21}+c_{22}+\ldots c_{2 m}+ \\
c_{q 1}+c_{q 2}+\ldots c_{q m}
\end{array}\right],\left[\begin{array}{l}
d_{11}+d_{12}+\ldots d_{1 m}+ \\
d_{21}+d_{22}+\ldots d_{2 m}+ \\
d_{q 1}+d_{q 2}+\ldots d_{q m}
\end{array}\right]\right]^{-1}} \\
& S_{F_{2}}^{w}=\left[a_{12}+a_{22}+\ldots a_{p 2}\right],\left[b_{12}+b_{22}+\ldots b_{p 2}\right],\left[c_{12}+c_{22}+\ldots c_{p 2}\right],\left[d_{12}+d_{22}+\ldots d_{p 2}\right] \otimes \\
& {\left[\left[\begin{array}{l}
a_{11}+a_{12}+\ldots a_{1 k}+ \\
a_{21}+a_{22}+\ldots a_{2 k}+ \\
a_{p 1}+a_{p 2}+\ldots a_{p k}
\end{array}\right],\left[\begin{array}{l}
b_{11}+b_{12}+\ldots b_{1 k}+ \\
b_{21}+b_{22}+\ldots b_{2 k}+ \\
b_{p 1}+b_{p 2}+\ldots b_{p k}
\end{array}\right],\left[\begin{array}{l}
c_{11}+c_{12}+\ldots c_{1 k}+ \\
c_{21}+c_{22}+\ldots c_{2 k}+ \\
c_{p 1}+c_{p 2}+\ldots c_{p k}
\end{array}\right],\left[\begin{array}{l}
d_{11}+d_{12}+\ldots d_{1 k}+ \\
d_{21}+d_{22}+\ldots d_{2 k}+ \\
d_{p 1}+d_{p 2}+\ldots d_{p k}
\end{array}\right]\right]^{-1}}
\end{aligned}
$$

\subsection{Fuzzified Pugh Matrix}

The fuzzy Pugh creates judgement matrices of the form $\tilde{P}=\left\{\tilde{p}_{g i}^{j}\right\}$ for all the sub features under a particular design feature using all the design concepts as baselines [42, 43]. The judgement matrices are aggregated with the weights of the sub features. It can be expressed as presented in equation 12. It is worthwhile to know that the aggregates in equation 12 will be obtained after the Pugh matrices have been repeated using all the design concepts as basis. In essence it can be deduced that for a design concept under consideration as basis then $p_{g 1}^{1}=p_{g 2}^{1}=\ldots \ldots=p_{g i}^{1}=1 \quad 1 \quad 1 \quad 1$. The aggregate of each design concept can be obtained from equation 13 .

$$
\begin{array}{cccccccc} 
& & \multicolumn{6}{c}{\text { Design Alternatives }} \\
& & D_{C_{1}} & D_{C_{2}} & \cdots & \cdots & \cdots & D_{C n} \\
& S_{F_{1}}^{w} & p_{g 1}^{1} & p_{g 1}^{2} & \cdots & \cdots & \cdots & p_{g 1}^{j} \\
& S_{F_{2}}^{w} & p_{g 2}^{1} & p_{g 2}^{2} & \cdots & \cdots & \cdots & p_{g 2}^{j} \\
\vdots & \vdots & \vdots & \cdots & \cdots & \cdots & \vdots \\
\vdots & \vdots & \vdots & \cdots & \cdots & \cdots & \vdots \\
& S_{F_{k}}^{w} & p_{g i}^{1} & p_{g i}^{2} & \cdots & \cdots & \cdots & p_{g i}^{j}
\end{array}
$$

Aggregate $\left[D_{C n}\right]_{\text {agg }} \ldots$ 


$$
\left.\left[D_{C n}\right]_{a g g}\right|_{j}=\sum_{i=1}^{i=i}\left(S_{F_{k}}^{w} * p_{g i}^{j}\right)
$$

\subsection{Fuzzy VIKOR}

A decision matrix is developed from all the aggregates of the Pugh matrices of the design features. The decision matrix is weighted by the relative importance of the design features ( $D_{F m}^{w}$ ) obtained from equation 4 . The matrix can be represented by equation 14 ;

$$
\begin{aligned}
& \begin{array}{lllll}
D_{C_{1}} & D_{C_{2}} & D_{C_{3}} & \cdots & D_{C n}
\end{array} \\
& \left.\left.\left.\left.D_{F_{1}}^{w} \quad\left[D_{C_{1}}\right]_{a g g}\right|_{1} ^{1}\left[D_{C_{2}}\right]_{a g g}\right|_{1} ^{2}\left[D_{C_{3}}\right]_{a g g}\right|_{1} ^{3} \quad \cdots \quad\left[D_{C n}\right]_{a g g}\right|_{1} ^{n} \\
& \left.\left.\left.\left.D_{F_{2}}^{w} \quad\left[D_{C_{1}}\right]_{\text {agg }}\right|_{2} ^{1}\left[D_{C_{2}}\right]_{a g g}\right|_{2} ^{2}\left[D_{C_{3}}\right]_{\text {agg }}\right|_{2} ^{3} \quad \cdots \quad\left[D_{C n}\right]_{a g g}\right|_{2} ^{n} \\
& \left.\left.\left.D_{F_{3}}^{w} \quad\left[D_{C_{1}}\right]_{\text {agg }}\right|_{3} ^{1}\left[D_{C_{2}}\right]_{\text {agg }}\right|_{3} ^{2}\left[D_{C_{3}}\right]_{\text {agg }}\right|_{3} ^{3} \quad \cdots \quad\left[\begin{array}{lll}
D_{C n} & ]\left._{\text {agg }}\right|_{3} ^{n}
\end{array}\right. \\
& \left.\left.\left.\left.D_{F_{m}}^{w} \quad\left[D_{C_{1}}\right]_{a g g}\right|_{m} ^{1}\left[D_{C_{2}}\right]_{a g g}\right|_{m} ^{2}\left[D_{C_{3}}\right]_{a g g}\right|_{m} ^{3} \quad \cdots \quad\left[D_{C n}\right]_{a g g}\right|_{m} ^{n}
\end{aligned}
$$

The fuzzy best $\left(\tilde{f}_{b}^{*}\right)$ and worst $\left(\tilde{f}_{w}^{-}\right)$values can be obtained from the decision matrix for all the design features as expressed in equations 15 and 16 respectively [44, 45]. Further, the separation measures which comprises of the maximum group utility values $\left(S_{n}\right)$ and the minimum individual regret values of the opponent design alternatives $\left(R_{n}\right)$ can also be obtained from equations 17 and 18 respectively $[46,47]$. The performance index VIKOR ( $Q_{n}$ ) is also obtained in terms of fuzzy number from the minimum and maximum values of the group utility and individual regret of the opponent design alternative as presented in equation 19 [48-50].

$$
\begin{aligned}
& \left.\tilde{f}_{b}^{*}\right|_{m}=\left.\operatorname{Max}_{n}\left[D_{C n}\right]_{a g g}\right|_{m} ^{n} \\
& \left.\tilde{f}_{w}^{-}\right|_{m}=\left.\operatorname{Min}_{n}\left[D_{C n}\right]_{a g g}\right|_{m} ^{n}
\end{aligned}
$$




$$
\begin{gathered}
S_{n}=\sum_{m=1}^{m=m}\left[\left(D_{F_{m}}^{w}\right) * \frac{\left(\left.\tilde{f}_{b}^{*}\right|_{m}-\left.\left[D_{C n}\right]_{a g g}\right|_{m} ^{n}\right)}{\left(\left.\tilde{f}_{b}^{*}\right|_{m}-\left.\tilde{f}_{w}^{-}\right|_{m}\right)}\right] \\
R_{n}=\operatorname{Max}_{m}\left[\left(D_{F_{m}}^{w}\right) * \frac{\left(\left.\tilde{f}_{b}^{*}\right|_{m}-\left.\left[D_{C n}\right]_{a g g}\right|_{m} ^{n}\right)}{\left(\left.\tilde{f}_{b}^{*}\right|_{m}-\left.\tilde{f}_{w}^{-}\right|_{m}\right)}\right] \\
Q_{n}=v\left[\frac{S_{n}-S^{*}}{S^{-}-S^{*}}\right]+(1-v)\left[\frac{R_{n}-R^{*}}{R^{-}-R^{*}}\right]
\end{gathered}
$$

Where $S^{*}=\operatorname{Min}_{n} S_{n} ; S^{-}=\operatorname{Max}_{n} S_{n} ; R^{*}=\operatorname{Min}_{n} R_{n} ; R^{-}=\underset{n}{\operatorname{Max}} R_{n}$. Also $v$ and $1-v$ represents the weight for the strategy of maximum group utility and the weight of the individual regret of an opponent strategy. $v$ usually assumed to be $0.5[45,46]$. The value of $Q_{n}$ is defuzzified ( $Q_{n}^{d f u}$ ) in order to obtain best nonfuzzy performance value for the design alternatives. The performance index VIKOR is defuzzified in equation 20 from the graded mean integrated method considering the trapezoidal fuzzy number described in equation 1 [39]. The optimal design concept $\left(D_{c n}^{o p t}\right)$ is the minimum of the best nonfuzzy performance value of $Q_{n}$ as presented in equation 21. Other concepts are also ranked in the same order such that the design concept with the highest defuzzified value is taken as the least.

$$
\begin{aligned}
& Q_{n}^{d f u}=\frac{1}{6}[a+2 b+2 c+d] \\
& D_{c n}^{o p t}=\operatorname{Min}_{n}\left\{Q_{n}^{d f u}\right\}
\end{aligned}
$$

\section{Application}

Four conceptual design of liquid spraying machine are considered as design alternatives with eight design features (Assembly and Disassembly (AD), Manufacturing (MA), Functionality (FU), Reliability (R), Maintainability (MN), Life Cycle Cost (LC), Serviceability (SE), Operation (OP) and Flexibility (FT)). These design features have different sub features as presented in Figure 2. An example of the fuzzified pairwise comparison matrix is developed 
in excel spread sheet for the design features as shown in Table 2. Further, Tables $A$ to $H$ in APPENDIX I presents the pairwise comparison matrices for the sub features considering each of the design features. However, the FSE results obtained for the sub features from these matrices are presented in Table 3. Fuzzified Pugh matrices are developed for all the design features using the design alternatives as basis as presented in Tables $I$ to $P$ in APPENDIX II. Aggregates are obtained from the weights of the sub features and the Pugh matrices representing the ranking of the availability of sub features in the component parts of the alternative design.

Table 2. Pairwise Comparison Matrix for the Design Features

\begin{tabular}{|c|c|c|c|c|c|c|c|}
\hline \multicolumn{8}{|c|}{ Design Features } \\
\hline$M A$ & $A D$ & $F U$ & $L C$ & $M N$ & $R E$ & $O P$ & $F T$ \\
\hline \multirow{2}{*}{$\begin{array}{llll}1 & 1 & 1 & 1\end{array}$} & 212 & \begin{tabular}{llll|}
7 & 9 & 11 & 13 \\
\end{tabular} & $1315 \quad 1719$ & 212 & 5,7 & $\begin{array}{llll}4 & 4 & 4 & 4\end{array}$ & $41315 \quad 1719$ \\
\hline & $\overline{5} \overline{2} \overline{3}^{1}$ & 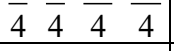 & $\overline{4} \overline{4} \overline{4} \quad \overline{4}$ & $5 \overline{2} 3$ & $2-\frac{2}{2}$ & $\begin{array}{llll}13 & \overline{11} & \overline{9} & 7\end{array}$ & $7 \begin{array}{lll}4 & 4 & 4\end{array}$ \\
\hline \multirow{2}{*}{$1 \frac{3}{2} 2 \frac{5}{2}$} & \multirow{2}{*}{$\begin{array}{llll}1 & 1 & 1 & 1\end{array}$} & $\begin{array}{lllll}7 & 9 & 11 & 13 \\
\end{array}$ & $\frac{5}{3} 3 \frac{7}{2} 4$ & $\begin{array}{llll}1 & 2 & 1 & 2\end{array}$ & \begin{tabular}{lll|}
5 & 7 \\
\end{tabular} & \multirow{2}{*}{\multicolumn{2}{|c|}{$1 \frac{3}{2} \quad 2 \quad \frac{5}{2} \quad \frac{13}{4} \frac{15}{4} \quad \frac{17}{4} \frac{19}{4}$}} \\
\hline & & 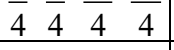 & $\overline{2}^{5} \overline{2}^{4}$ & $\begin{array}{llll}4 & \overline{7} & \overline{3} & \overline{5} \\
\end{array}$ & $\overline{2}^{3} \overline{2}^{4}$ & & \\
\hline $\begin{array}{llll}4 & 4 & 4 & 4\end{array}$ & \multirow{2}{*}{$\frac{4}{13} \frac{4}{11} \frac{4}{9}$} & \multirow{2}{*}{$\begin{array}{llll}1 & 1 & 1 & 1\end{array}$} & $\begin{array}{llll}7 & 9 & 11 & 13\end{array}$ & $\begin{array}{llll}13 & 15 & 17 & 19\end{array}$ & 79 & \multirow{2}{*}{\multicolumn{2}{|c|}{$\frac{7}{4} \frac{9}{4} \frac{11}{4} \frac{13}{4} \quad \frac{5}{2} 3 \frac{7}{2} 4$}} \\
\hline $\begin{array}{llll}\overline{13} & \overline{11} & \overline{9} & \overline{7}\end{array}$ & & & 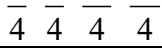 & \begin{tabular}{llll|}
4 & $\overline{4}$ & $\overline{4}$ & 4 \\
\end{tabular} & $\overline{4} \overline{4}$ & & \\
\hline $\begin{array}{llll}4 & 4 & 4 & 4\end{array}$ & $12 \underline{2} \quad 2$ & $\begin{array}{llll}4 & 4 & 4 & 4\end{array}$ & \multirow{2}{*}{$\begin{array}{llll}1 & 1 & 1 & 1\end{array}$} & \multirow{2}{*}{$\frac{5}{2} 3 \frac{7}{2} 4$} & $\underline{3} 2$ & \multirow{2}{*}{$\frac{2}{5} \frac{1}{2} \frac{2}{3} 1$} & \multirow{2}{*}{$1 \frac{3}{2} 2 \frac{5}{2}$} \\
\hline$\overline{19} \overline{17} \quad \overline{15} \overline{13}$ & $\overline{4} \overline{7} \overline{3} \quad \overline{5}$ & 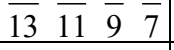 & & & $\mid \begin{array}{lll}1 & \overline{2} & 2 \\
\end{array}$ & & \\
\hline \multirow{2}{*}{$1 \frac{3}{2} 2 \frac{5}{2}$} & \multirow{2}{*}{$\frac{5}{2} 3 \frac{7}{2} 4$} & 44 & $12 \quad 2 \quad 12$ & \multirow{2}{*}{$\begin{array}{lllll}1 & 1 & 1 & 1\end{array}$} & $\begin{array}{lll}4 & 4 & 4\end{array}$ & \multirow{2}{*}{$\frac{2}{5} \frac{1}{2} \frac{2}{3} 1$} & \multirow{2}{*}{$\frac{7}{4} \frac{9}{4} \frac{11}{4} \frac{13}{4}$} \\
\hline & & $\overline{19} \overline{17} \quad \overline{15} \overline{13}$ & $\begin{array}{l}4 \quad \overline{7} \\
\end{array} \overline{5}$ & & $13 \quad \overline{11} \quad \overline{9}$ & & \\
\hline $1 \underline{2} \leq 2$ & 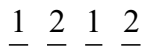 & $4 \quad 4 \quad \underline{4} \quad \underline{4}$ & $2 \underline{1} 2$ & $\begin{array}{llll}7 & 9 & 11 & 13\end{array}$ & \multirow{2}{*}{$\begin{array}{lllll}1 & 1 & 1 & 1\end{array}$} & \multirow{2}{*}{$1 \frac{3}{2} 2 \frac{5}{2}$} & \multirow{2}{*}{$\frac{7}{4} \frac{9}{4} \frac{11}{4} \frac{13}{4}$} \\
\hline 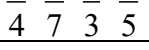 & 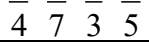 & $\overline{13} \quad \overline{11} \quad \overline{9} \quad \overline{7}$ & $\overline{5} \overline{2} \overline{3}$ & $\overline{4} \overline{4} \overline{4}$ & & & \\
\hline $7 \quad \underline{9} \quad 11 \quad 13$ & $2 \frac{1}{2}$ & $4 \quad 4 \quad 4$ & $\underline{3}$ & 5 & $\begin{array}{lll}2 & 1 & 2\end{array}$ & \multirow{2}{*}{$\begin{array}{llll}1 & 1 & 1 & 1\end{array}$} & \multirow{2}{*}{$\frac{5}{2} 3 \frac{7}{2} 4$} \\
\hline & $\overline{5} \overline{2} \overline{3}^{1}$ & $\begin{array}{llll}\overline{13} & \overline{11} & \overline{9} & \overline{7} \\
\end{array}$ & $\overline{2}$ & $\overline{2}$ & $\overline{5} \overline{2} \overline{3}$ & & \\
\hline \multirow{2}{*}{$\frac{4}{19} \frac{4}{17} \frac{4}{15} \frac{4}{13}$} & 4444 & $1 \underline{2} 1 \underline{2}$ & $2 \underline{1}-2$ & $\begin{array}{llll}4 & 4 & 4 & 4\end{array}$ & $4 \underline{4}$ & $2 \quad 1 \quad 2$ & \multirow{2}{*}{$\begin{array}{llll}1 & 1 & 1 & 1\end{array}$} \\
\hline & 19171513 & $\begin{array}{llll}4 & 7 & 3 \\
\end{array}$ & $5 \overline{2} 3$ & $\begin{array}{ll}13 & \overline{11} \\
\end{array}$ & $\begin{array}{lll}\overline{13} & \overline{11} & \overline{9}\end{array}$ & $5 \overline{2} 3$ & \\
\hline \multicolumn{8}{|c|}{ FSEs } \\
\hline$M A$ & $A D$ & $F \boldsymbol{F}$ & $L C$ & $M N$ & $R E$ & $O P$ & $F T$ \\
\hline $26 \underline{18} 2$ & $532 \underline{2}$ & $31413 \underline{16}$ & 3329 & 23119 & $5 \quad 4 \quad 7 \quad 1$ & $5 \quad 4 \quad 3 \quad 2$ & 2314 \\
\hline$\overline{19} \overline{4189} \overline{7}$ & $\overline{46} \overline{19} \overline{19}$ & $\overline{29} \overline{95} \overline{63} \overline{55}$ & $\overline{55} \overline{37} \overline{17} \overline{52}$ & $33 \overline{34} \overline{87} \overline{49}$ & $\overline{91} \overline{49} \overline{59} \overline{8}$ & $\overline{73} \overline{39} \overline{20} \overline{9}$ & $\overline{79} \overline{89} \overline{21} \overline{55}$ \\
\hline
\end{tabular}




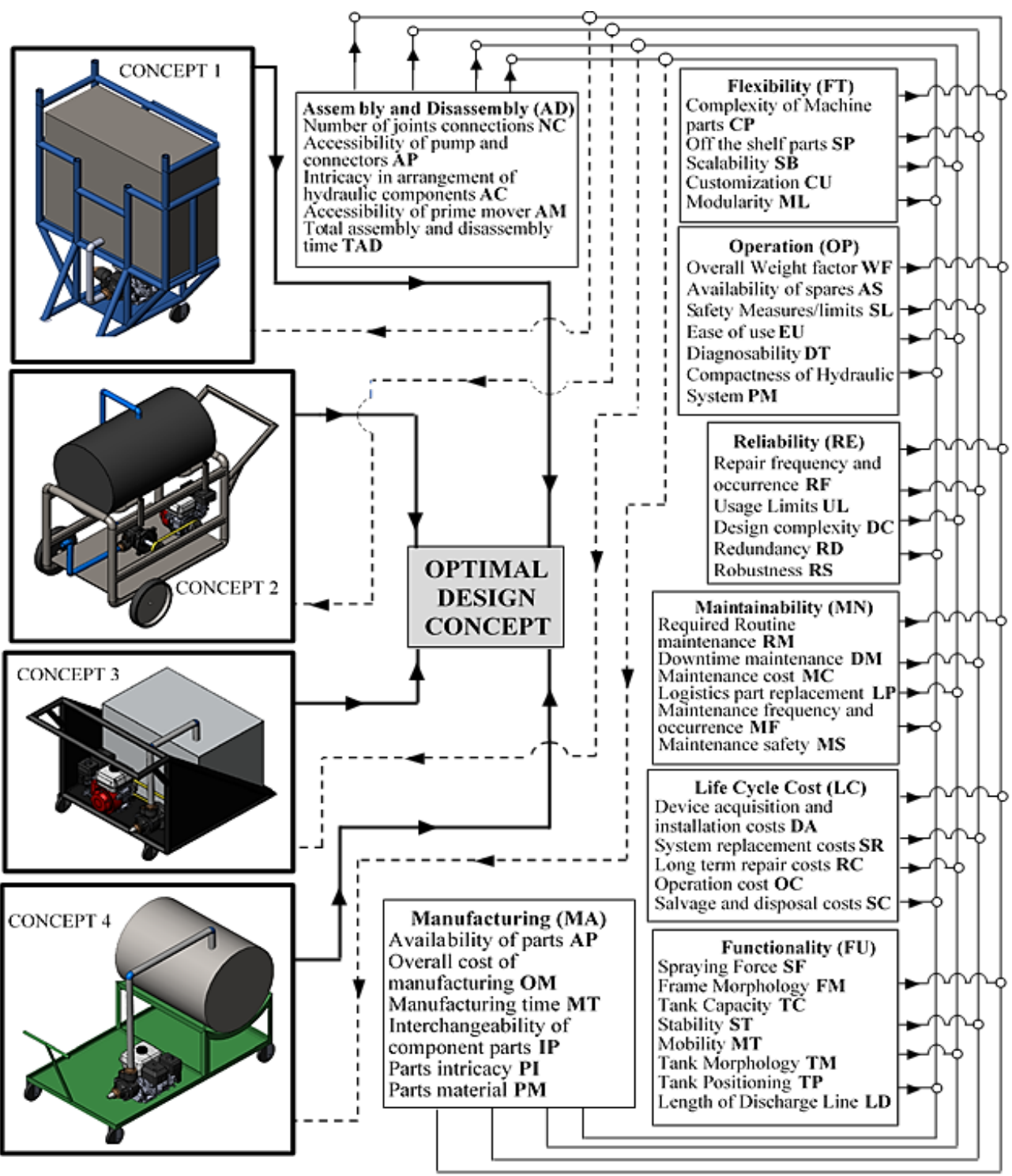

Figure 2. Application of the Integrated Model to Conceptual design of Liquid Spraying Machine

Table 3. FSEs obtained from Pairwise comparison matrices of sub features

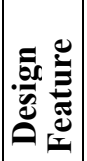

Sub features 


\begin{tabular}{|c|c|c|c|c|c|c|}
\hline \multirow{3}{*}{ MA } & $A P$ & $O M$ & $M T$ & $I P$ & $P I$ & $P M$ \\
\hline & $\begin{array}{llll}5 & 5 & 17 & 6\end{array}$ & 72151 & $\begin{array}{llll}3 & 7 & 5 & 12\end{array}$ & $\begin{array}{llll}3 & 4 & 4 & 9\end{array}$ & $\begin{array}{llll}4 & 1 & 5 & 9\end{array}$ & 213111 \\
\hline & 63419523 & 3982142 & 52793861 & 64594162 & 97186371 & 1149023 \\
\hline \multirow{3}{*}{ AD } & $N C$ & $A P$ & $A C$ & $A M$ & $T A D$ & \\
\hline & $\begin{array}{llll}3 & 1 & 2 & 7\end{array}$ & $\begin{array}{llll}2 & 7 & 3 & 11\end{array}$ & 114714 & 51213 & 42747 & \\
\hline & $\overline{71} \overline{19} \overline{29} \overline{79}$ & $\overline{21} \overline{55} \overline{17} \overline{46}$ & $\overline{989} \overline{31} \overline{45}$ & $365 \overline{734}$ & $\overline{17} \overline{91} \overline{12}$ & \\
\hline \multirow{3}{*}{ FU } & $F M$ & $S T$ & $M T$ & $T M$ & $L D$ & \\
\hline & $\begin{array}{llll}5 & 5 & 5 & 16\end{array}$ & $\begin{array}{llll}3 & 4 & 5 & 6\end{array}$ & $\begin{array}{llll}1 & 9 & 8 & 1\end{array}$ & 41102 & 16162631 & $\begin{array}{llll}4 & 7 & 3 & 1\end{array}$ \\
\hline & $49 \overline{36} \overline{26} \overline{61}$ & $\overline{82} \overline{85} \overline{78} \overline{67}$ & 858333 & 519639 & $\overline{85} \overline{61} \overline{71} \overline{63}$ & $51 \overline{5917}$ \\
\hline \multirow{3}{*}{ LC } & $\mathrm{DA}$ & $S R$ & $\mathrm{RC}$ & $O C$ & $S C$ & \\
\hline & 9202610 & $\begin{array}{llll}2 & 7 & 1 & 2 \\
\end{array}$ & $5 \quad 101315$ & 111455 & 3111216 & \\
\hline & $\overline{58} \overline{97} \overline{9527}$ & $35 \overline{87} \overline{13}$ & $\overline{47} \overline{67} \overline{63} \overline{52}$ & $\overline{48} \overline{45} \overline{12} \overline{9}$ & $\overline{34} \overline{95} \overline{79} \overline{79}$ & \\
\hline \multirow{3}{*}{$\mathbf{M N}$} & $\boldsymbol{R M}$ & $D M$ & $M C$ & $L P$ & $M F$ & $M S$ \\
\hline & $\begin{array}{llll}5 & 1 & 14 & 4\end{array}$ & $\begin{array}{llll}3 & 1 & 11 & 7 \\
\end{array}$ & 11112323 & $4 \quad 7 \quad 155$ & $\begin{array}{lll}4 & 11 & 1\end{array}$ & 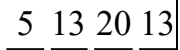 \\
\hline & $\overline{73} \overline{10} \overline{97} \overline{19}$ & $\overline{5012} \overline{94} \overline{41}$ & 70507655 & $\overline{49} \overline{60} \overline{91} \overline{21}$ & 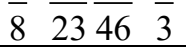 & $\overline{48} \overline{86} \overline{93} \overline{42}$ \\
\hline \multirow{3}{*}{ RE } & $R F$ & $U L$ & $D C$ & $R D$ & $R S$ & \\
\hline & $7 \quad 1522$ & 29313 & 5101317 & $\begin{array}{llll}2 & 1 & 1 & 1 \\
\end{array}$ & $1137 \quad 1$ & \\
\hline & 4651963 & 1137967 & 67999589 & 49201612 & $\overline{56} \overline{11} \overline{19} \quad \overline{2}$ & \\
\hline \multirow{3}{*}{ OP } & WF & $A S$ & $S L$ & $E U$ & $D T$ & $P M$ \\
\hline & $\begin{array}{llll}9 & 9 & 13 & 1\end{array}$ & $\begin{array}{llll}1 & 6 & 6 & 12 \\
\end{array}$ & $\begin{array}{llll}7 & 11919\end{array}$ & $9 \quad 1722 \quad 15$ & $\begin{array}{llll}3 & 3 & 5 & 2 \\
\end{array}$ & $\begin{array}{llll}3 & 4 & 8 & 12 \\
\end{array}$ \\
\hline & $\overline{98} \overline{70} \overline{73} \overline{4}$ & $\overline{10} \overline{41} \overline{29} \overline{41}$ & 7479262 & $\overline{47} \overline{63} \overline{59} \overline{29}$ & $\overline{49} \overline{35} \overline{41} \overline{11}$ & $\overline{62} \overline{57} \overline{79} \overline{79}$ \\
\hline \multirow{3}{*}{ FT } & $C P$ & $S P$ & $S B$ & $C U$ & $M L$ & \\
\hline & $\begin{array}{lll}2 & 5 & 25 \\
177\end{array}$ & 31416 & 111711 & $\begin{array}{llll}2 & 1 & 1 & 3 \\
\end{array}$ & 1172320 & \\
\hline & $\overline{15} \overline{27} \overline{97} \overline{46}$ & $\overline{17} \overline{57} \overline{3} \overline{13}$ & $\overline{9} \overline{70} \overline{32} \overline{36}$ & $\overline{45} \overline{18} \overline{14} \overline{31}$ & $\overline{7} \overline{82} \overline{79} \overline{49}$ & \\
\hline
\end{tabular}

The aggregates of the design alternatives from the Pugh matrices in Tables $I$ to $P$ in APPENDIX II are used to develop the decision matrix from which the fuzzy best and worst values can be obtained. The decision matrix, fuzzy best and worst values are presented in Table 4. Further, the separation measures are obtained from equations 15 and 16 from the fuzzified decision matrix in Table 4, weight of the design features and the fuzzified worst and best values. Also, the performance index value in the form of $\mathrm{TrFN}$ is obtainable from equation 17 using the separation measures. Finally, the best nonfuzzy performance value of the $n$th design alternative is obtained from the defuzzification of the fuzzified performance index by applying equation 18 and the ranking was achieved using equation 19 as presented in Table 5.

Table 4. Fuzzified Decision Matrix and Fuzzy Best and Worst Values

\begin{tabular}{|c|c|c|c|c|}
\hline \multirow{2}{*}{$\begin{array}{c}\text { Design } \\
\text { features }\end{array}$} & \multicolumn{4}{|c|}{ Fuzzified Decision Matrix } \\
\cline { 2 - 5 } & Concept 1 & Concept 2 & Concept 3 & Concept 4 \\
\cline { 2 - 5 } & & Concepts \\
\hline
\end{tabular}




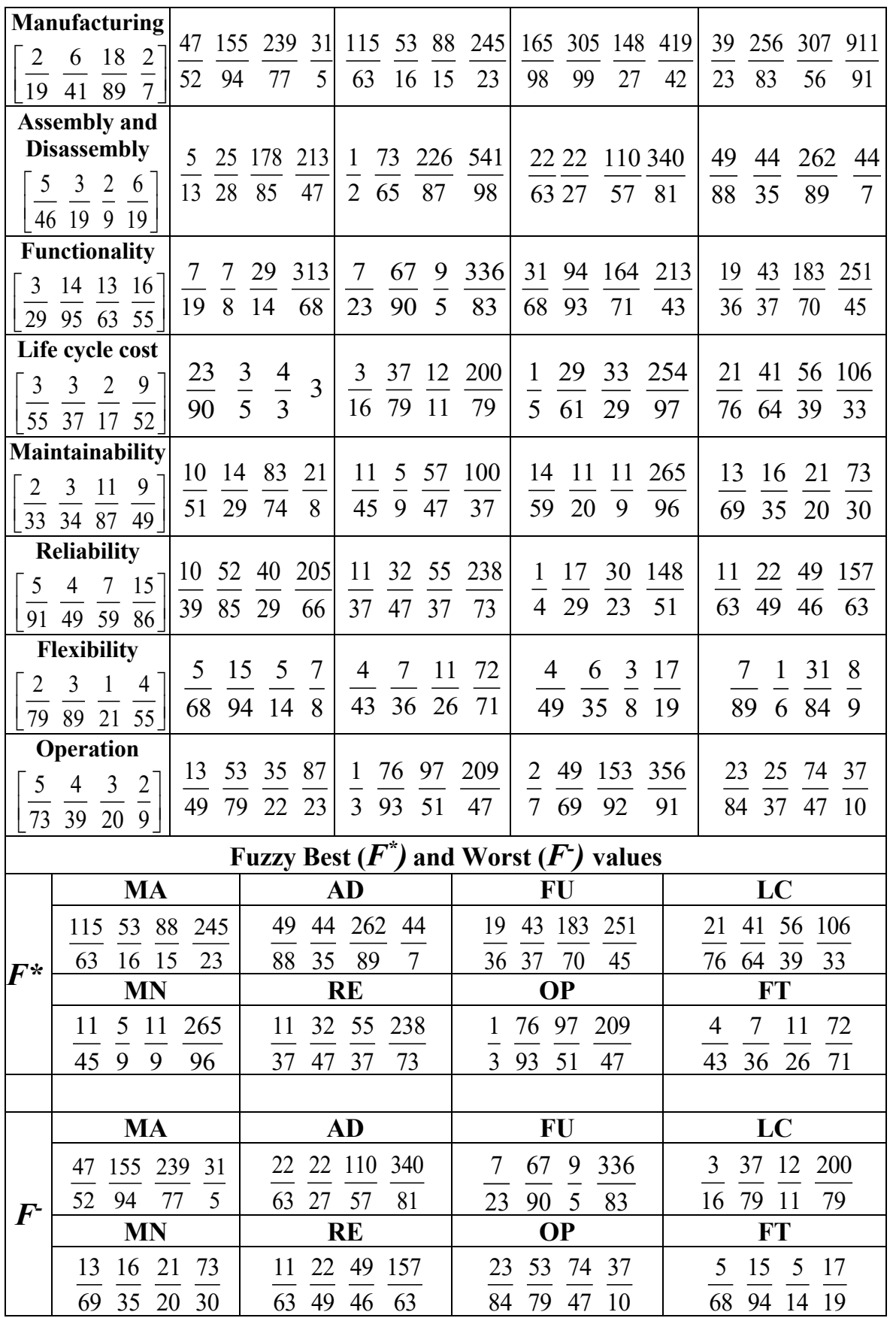


Table 5. Separation Measures, Performance Index and Ranking of design concepts

\begin{tabular}{|c|c|c|c|c|c|c|c|c|c|c|c|}
\hline \multirow{2}{*}{$\begin{array}{c}\text { Design } \\
\text { Concepts }\end{array}$} & \multicolumn{8}{|c|}{ Separation Measures } & \multirow{2}{*}{$\begin{array}{c}\begin{array}{c}\text { Performance } \\
\text { Index VIKOR }\end{array} \\
Q_{i}\end{array}$} & \multirow{2}{*}{$\begin{array}{c}\text { Defuzzified } \\
\text { Value of } Q_{i}\end{array}$} & \multirow[t]{2}{*}{ Ranking } \\
\hline & \multicolumn{4}{|c|}{$S_{i}$} & \multicolumn{4}{|c|}{$R_{i}$} & & & \\
\hline \multirow{2}{*}{ Concept 1} & & 38 & 59 & 19 & & 6 & 18 & & $\begin{array}{llll}31 & 13 & 19 & 41\end{array}$ & 4 & \multirow{2}{*}{$4^{\text {th }}$} \\
\hline & & 6 & $1 \overline{69}$ & $\overline{16}$ & & $\overline{41}$ & $\overline{89}$ & $\overline{7}$ & 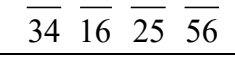 & $\overline{5}$ & \\
\hline \multirow{2}{*}{ Concept 2} & & 21 & 11 & 41 & & 14 & 13 & & $\begin{array}{llll}27 & 15 & 21 & 49\end{array}$ & 13 & \multirow{2}{*}{$1^{\text {st }}$} \\
\hline & $\overline{91}$ & $\overline{76}$ & $\overline{27}$ & $\overline{67}$ & $\overline{29}$ & $\overline{95}$ & $\overline{63}$ & $\overline{55}$ & $\overline{49} \overline{29} \quad \overline{41} \overline{96}$ & $\overline{25}$ & \\
\hline \multirow{2}{*}{ Concept 3} & 17 & 4 & 62 & 49 & & 3 & 2 & & $\begin{array}{llll}16 & 63 & 3 & 27\end{array}$ & 22 & \multirow{2}{*}{$3^{\text {rd }}$} \\
\hline & $\overline{56}$ & 9 & $\overline{99}$ & $\overline{52}$ & $\overline{46}$ & $\overline{19}$ & $\overline{9}$ & $\overline{19}$ & $\overline{21} \overline{83} \quad \overline{4} \quad \overline{35}$ & 29 & \\
\hline \multirow{2}{*}{ Concept 4} & $\underline{3}$ & 49 & 59 & 43 & & 14 & 13 & 16 & $\begin{array}{llll}11 & 58 & 73 & 29\end{array}$ & 43 & \multirow{2}{*}{$2^{\text {nd }}$} \\
\hline & $\overline{8}$ & $\overline{90}$ & $\overline{75}$ & $\overline{37}$ & $\overline{29}$ & $\overline{95}$ & $\overline{63}$ & $\overline{55}$ & $\overline{14} \overline{77} \quad \overline{98} \quad \overline{39}$ & $\overline{57}$ & \\
\hline
\end{tabular}

\section{Discussions and Conclusion}

Considering the results obtained from the hybridized model by integration of fuzzy AHP, Fuzzy Pugh Matrix and Fuzzy VIKOR, it is clear that design concept two is the optimal design. However, there are discrepancies in the best nonfuzzy performance value of the design alternatives. This discrepancy can be observed from the non-consistency in the difference of the final defuzzified value of the performance indices of the design alternatives. The differences in the final value of the design alternatives is an indication that the hybridized model allots values to the design alternatives according to their performance in terms of design features and sub features. Also, the higher difference between the best nonfuzzy performance of design concept two (which is the optimal design concept) and concept four (which is the second optimal design concept) is an indication that design concept two performs excellently than its close alternative in the decision process. However, the difference between concept four and concept three (which is the third optimal design concept) is very small which indicates that the performance of the two concepts is almost the same in terms of their closeness to the optimal design concept and as such the manufacturer can decide whether to select any of these two as the next option to the optimal design. However, since there is a difference between the performance of these two alternatives to design concept one (which has the least performance in the decision process), the design engineer may reconsider selecting the concept with the largest difference to concept one as the second optimal design. In essence, the final results obtained from the decision process has provided a useful insight to the design engineer and manufacturer in terms of the design concept with the best performance. In view of this, it can be hypothetically stated that the hybridized model makes distinctive decision that a design concept is better than other alternatives.

Further, it can also be stated that the improved performance of the hybridized model may be due to two reasons. The first reason is the involvement of the weights of the design 
features in the computation of separation measures. This increases the dependency of the best nonfuzzy performance value of the optimal design concept on weights of the design features which also causes the difference in the final values of the design concepts. In essence, a notable variation in the final values of the design concepts can be obtained from the hybridized model. The second reason is the iterative comparison which is structured by using all the design alternatives as basis and inclusion of the weight of sub features in the process of developing the elements of the fuzzified decision matrix. In the hybridized model proposed in this article, the iterative comparison of the design alternatives considering the sub features (as described Tables $I$ to $P$ in Appendix II) is a unique way of arriving at a decision matrix which makes it a different approach compare to other decision analysis. This ensures that all the design alternatives have been considered as basis in the decision process for each of the sub features under a design feature. This method may be considered as an elaboration of the conventional Pugh matrix in which the weights of the design features are used in conjunction with applying one of the design alternatives as the basis in the decision process. The advantage of considering all the design alternatives as basis of comparison using the weights of the sub features is that it ensures a thorough analysis in the decision process because it ensures that there is no bias judgement that can occur from apportioning of values to the availability of design features or sub features in the alternative designs. In view of this, the study has been able to proof that integrating Fuzzy AHP, Fuzzy Pugh Matrix and Fuzzy VIKOR can produce effective results for decisions on optimal design concept.

Further, a good but cumbersome way to compare the proposed hybridized model in the present study with other models is to carry out decision analysis with other models considering the same alternative designs used in the present study. This may increase the number of working tables to be presented and it may shift the purpose of the article because there will be many methods to consider. However, an excellent way to compare the proposed hybridized model with previous model is to consider the analysis involved in the development of the decision matrix. As stated earlier, it is evident that the hybridized model presented in this article allows comparison of all design alternatives by considering all the sub features in the process of developing the decision matrix because it is from the aggregates of this comparison that the elements of the design matrix are obtained. In other studies, the decision matrix is usually obtained by apportioning crisp values [5, 14] or fuzzy numbers [1] to represent the availability of design features in the design alternatives. Also, in other studies involving application of hybridized multi attribute decision models to conceptual design, the decision matrices are created by aggregating the availability of sub features in the alternative designs using fuzzy numbers $[34,35]$. The reliability of these methods depends on the expertise of the design engineers to accurately quantify the availability of the sub features in the alternatives. Also, other studies that involves the application of hybridized multi attribute decision models usually employs the opinion of experts or group of decision makers to aggregate the availability of sub criteria in the alternatives in order to create the fuzzified decision matrix [28-30]. Hence the iterative approach proposed in the present study provides a non-bias fuzzified values for the elements of the decision matrix. 
To this end, it can be concluded that conceptual design phase in engineering involves a decision-making process that provides optimal design concept from a set of alternative design concepts. In order to achieve the efficient selection of optimal design concept, it is necessary to consider a holistic approach by considering all necessary design features and sub features. However, the process becomes complex because of the numerous features considered. The present study has been able to prove that the application of hybridized multi-criteria decision models is a promising way of providing a systematic computation in the decision process in order to avoid the bias nature of over grading a design feature or its sub feature. The essence of these pairwise matrices is to ensure that the weights of the design features and sub features are obtained from allocation of linguistic terms in the form of trapezoidal fuzzy numbers by design experts and the fuzzy synthetic extent evaluation provides a methodical technique of deriving the weights from the pairwise matrix. Further, it is difficult to ascertain that a design concept is better than the other by apportioning of points in a decision matrix but the introduction of the fuzzified Pugh matrix using all the design concept as basis has assisted in creating an non-bias judgement process because the strength and weaknesses of all the design alternatives has been considered for all the design features. In essence, modelling decision making problem in engineering design as a multicriteria decision analysis and solving the problem using an integrated multicriteria decision analysis model is a promising approach to decision making in conceptual engineering design. However, considering the hybridized model presented in the present study, future work is possible in the aspect of developing the model into an application rather than the excel spread sheet used in the present study. Such application should be developed to enable users or decision makers to input the necessary design features and sub features alongside their relationships in order to facilitate the computational process in the decision analysis. The application may also implement a CAD based graphic interface where parts can be matched with features in order to support analysis of the alternative conceptual designs in the decision process.

\section{References}

[1] Olabanji, O.M., Reconnoitering the suitability of fuzzified weighted decision matrix for design process of a reconfigurable assembly fixture. International Journal of Design Engineering. 8(1): p. 38-56, 2018.

[2] Renzi, C. and F. Leali, A multicriteria decision-making application to the conceptual design of mechanical components. Journal of Multi-Criteria Decision Analysis. 23(3-4): p. 87-111, 2016.

[3] Renzi, C., F. Leali, M. Pellicciari, A.O. Andrisano, and G. Berselli, Selecting alternatives in the conceptual design phase: an application of Fuzzy-AHP and Pugh's Controlled Convergence. International Journal on Interactive Design and Manufacturing (IJIDeM). 9(1): p. 1-17, 2015. 
[4] Renzi, C., F. Leali, and L. Di Angelo, A review on decision-making methods in engineering design for the automotive industry. Journal of Engineering Design. 28(2): p. 118-143, 2017.

[5] Olabanji, O.M. and K. Mpofu, Comparison of weighted decision matrix, and analytical hierarchy process for CAD design of reconfigurable assembly fixture, in Procedia CIRP. 2014. p. 264-269.

[6] Yeo, S., M. Mak, and S. Balon, Analysis of decision-making methodologies for desirability score of conceptual design. Journal of Engineering Design. 15(2): p. 195208, 2004.

[7] Girod, M., A. Elliott, N.D. Burns, and I. Wright, Decision making in conceptual engineering design: an empirical investigation. Proceedings of the Institution of Mechanical Engineers, Part B: Journal of Engineering Manufacture. 217(9): p. 12151228, 2003.

[8] Derelöv, M., On Evaluation of Design Concepts: Modelling Approaches for Enhancing the Understanding of Design Solutions. 2009, Linköping University Electronic Press.

[9] Nikander, J.B., L.A. Liikkanen, and M. Laakso, The preference effect in design concept evaluation. Design studies. 35(5): p. 473-499, 2014.

[10] Jugulum, R. and D.D. Frey, Toward a taxonomy of concept designs for improved robustness. Journal of Engineering Design. 18(2): p. 139-156, 2007.

[11] Mattson, C.A. and A. Messac, Pareto frontier based concept selection under uncertainty, with visualization. Optimization and Engineering. 6(1): p. 85-115, 2005.

[12] Hambali, A., S. Sapuan, A. Rahim, N. Ismail, and Y. Nukman, Concurrent decisions on design concept and material using analytical hierarchy process at the conceptual design stage. Concurrent Engineering. 19(2): p. 111-121, 2011.

[13] Sa'Ed, M.S. and M.Y. Al-Harris, New product concept selection: an integrated approach using data envelopment analysis (DEA) and conjoint analysis (CA). International Journal of Engineering \& Technology. 3(1): p. 44, 2014.

[14] Hambali, A., S. Sapuan, N. Ismail, and Y. Nukman, Application of analytical hierarchy process in the design concept selection of automotive composite bumper beam during the conceptual design stage. Scientific Research and Essays. 4(4): p. 198-211, 2009.

[15] Radhakrishnan, R. and D.A. McAdams, A methodology for model selection in engineering design. Journal of mechanical design. 127(3): p. 378-387, 2005.

[16] Green, G. and G. Mamtani, An integrated decision making model for evaluation of concept design. Acta Polytechnica. 44(3) 2004.

[17] Saridakis, K.M. and A.J. Dentsoras, Soft computing in engineering design-A review. Advanced Engineering Informatics. 22(2): p. 202-221, 2008.

[18] Okudan, G.E. and R.A. Shirwaiker. A multi-stage problem formulation for concept selection for improved product design. in 2006 Technology Management for the Global Future-PICMET 2006 Conference. IEEE 2006.

[19] Akay, D., O. Kulak, and B. Henson, Conceptual design evaluation using interval type-2 fuzzy information axiom. Computers in Industry. 62(2): p. 138-146, 2011.

[20] Mardani, A., A. Jusoh, K. Nor, Z. Khalifah, N. Zakwan, and A. Valipour, Multiple criteria decision-making techniques and their applications-a review of the literature from 2000 to 2014. Economic Research-Ekonomska Istraživanja. 28(1): p. 516-571, 2015.

[21] Xiao, A., S.S. Park, and T. Freiheit. A comparison of concept selection in concept scoring and axiomatic design methods. in Proceedings of the Canadian Engineering Education Association (CEEA). 2007. 
[22]Roy, B. and D. Vanderpooten, The European School of MCDA: Emergence, Basic Features and Current Works. Journal of Multi-Criteria Decision Analysis. 5(1): p. pp. 22-38, 1996.

[23] Roy, B., Main Sources of Inaccurate Determination, Uncertainty and Imprecision in Decision Models. Mathl. Comput. Modelling 12(10-11): pp. 1245-1254, 1989.

[24]Ho, W., X. Xu, and P.K. Dey, Multi-criteria decision making approaches for supplier evaluation and selection: A literature review. European Journal of operational research. 202(1): p. 16-24, 2010.

[25] Okudan, G.E. and S. Tauhid, Concept selection methods-a literature review from 1980 to 2008. International Journal of Design Engineering. 1(3): pp. 243-277, 2008.

[26] Belton, V. and T. Stewart, MULTIPLE CRITERIA DECISION ANALYSIS: An Integrated Approach. 2002: Springer Science+Business Media Dordrecht. pp. 13-52; ISBN 978-1-4615-1495-4 (eBook).

[27] Ortiz-Barrios, M.A., B. Kucukaltan, D. Carvajal-Tinoco, D. Neira-Rodado, and G. Jiménez, Strategic hybrid approach for selecting suppliers of high-density polyethylene. Journal of Multi-Criteria Decision Analysis. 24(5-6): pp. 296-316, 2017.

[28] Alarcin, F., A. Balin, and H. Demirel, Fuzzy AHP and Fuzzy TOPSIS integrated hybrid method for auxiliary systems of ship main engines. Journal of Marine Engineering \& Technology. 13(1): pp. 3-11, 2014.

[29] Nazam, M., J. Xu, Z. Tao, J. Ahmad, and M. Hashim, A fuzzy AHP-TOPSIS framework for the risk assessment of green supply chain implementation in the textile industry. International Journal of Supply and Operations Management. 2(1): pp. 548, 2015.

[30] Balin, A., H. Demirel, and F. Alarcin, A novel hybrid MCDM model based on fuzzy AHP and fuzzy TOPSIS for the most affected gas turbine component selection by the failures. Journal of Marine Engineering \& Technology. 15(2): pp. 69-78, 2016.

[31] Glaize, A., A. Duenas, C. Di Martinelly, and I. Fagnot, Healthcare decision-making applications using multicriteria decision analysis: A scoping review. Journal of MultiCriteria Decision Analysis, 26(1-2): pp. 62-83. 2019.

[32] Zeynali, M., M.H. Aghdaie, N. Rezaeiniya, and S.H. Zolfani, A hybrid fuzzy multiple criteria decision making (MCDM) approach to combination of materials selection. African Journal of Business Management. 6(45): pp. 11171-11178, 2012.

[33] Kundakc1, N., An integrated method using MACBETH and EDAS methods for evaluating steam boiler alternatives. Journal of Multi-Criteria Decision Analysis. 26(12): p. 27-34, 2019.

[34] Olabanji, O. and K. Mpofu, Hybridized fuzzy analytic hierarchy process and fuzzy weighted average for identifying optimal design concept. Heliyon, Elsevier. 6(1): p. 1$13,2020$.

[35] Olabanji, O.M. and K. Mpofu, Adopting hybridized multicriteria decision model as a decision tool in engineering design. Journal of Engineering, Design and Technology. 18(2): p. 451-479, 2020.

[36] Velu, L.G.N., J. Selvaraj, and D. Ponnialagan, A new ranking principle for ordering trapezoidal intuitionistic fuzzy numbers. Complexity. 20172017.

[37] Singh, P., A Novel Method for Ranking Generalized Fuzzy Numbers. J. Inf. Sci. Eng. 31(4): p. 1373-1385, 2015.

[38] Nieto-Morote, A. and F. Ruz-Vila, A fuzzy AHP multi-criteria decision-making approach applied to combined cooling, heating, and power production systems. 
International Journal of Information Technology \& Decision Making. 10(03): p. 497517, 2011.

[39]Zamani, S., H. Farughi, and M. Soolaki, Contractor selection using fuzzy hybrid AHPVIKOR. International Journal of Research in Industrial Engineering. 2(4): p. 26-40, 2014.

[40] Tian, J. and Z. Yan, Fuzzy analytic hierarchy process for risk assessment to generalassembling of satellite. Journal of applied research and technology. 11(4): p. 568-577, 2013.

[41] Somsuk, N. and C. Simcharoen, A fuzzy AHP approach to prioritization of critical success factors for six sigma implementation: Evidence from the electronics industry in thailand. International Journal of Modeling and Optimization. 1(5): p. 432-437, 2011.

[42] Muller, G. Concept selection: theory and practice. in White paper of SESG meeting. sl: Buskerud University College. 2009.

[43] Muller, G., D. Klever, H.H. Bjørnsen, and M. Pennotti, Researching the application of Pugh Matrix in the sub-sea equipment industry, in CSER. 2011.

[44] Musani, S. and A.A. Jemain. Ranking schools' academic performance using a fuzzy VIKOR. in Journal of Physics: Conference Series. IOP Publishing 2015.

[45] Shemshadi, A., H. Shirazi, M. Toreihi, and M.J. Tarokh, A fuzzy VIKOR method for supplier selection based on entropy measure for objective weighting. Expert Systems with Applications. 38(10): p. 12160-12167, 2011.

[46] Opricovic, S., Fuzzy VIKOR with an application to water resources planning. Expert Systems with Applications. 38(10): p. 12983-12990, 2011.

[47] Kim, Y. and E.-S. Chung, Fuzzy VIKOR approach for assessing the vulnerability of the water supply to climate change and variability in South Korea. Applied Mathematical Modelling. 37(22): p. 9419-9430, 2013.

[48] Chang, T.-H., Fuzzy VIKOR method: A case study of the hospital service evaluation in Taiwan. Information Sciences. 271: p. 196-212, 2014.

[49]Bag, S., Fuzzy VIKOR approach for selection of big data analyst in procurement management. Journal of Transport and Supply Chain Management. 10(1): p. 1-6, 2016.

[50] Afful-Dadzie, E., S. Nabareseh, Z.K. Oplatková, and P. Klímek, Model for assessing quality of online health information: A fuzzy VIKOR based method. Journal of MultiCriteria Decision Analysis. 23(1-2): p. 49-62, 2016.

Received: 5.03.2020, Accepted: 28.09.2020 


\section{APPENDIX I}

Table A. Pairwise Comparison Matrix for Sub features of Manufacturing

\begin{tabular}{|c|c|c|c|c|c|c|}
\hline \multicolumn{7}{|c|}{ Manufacturing MA } \\
\hline & $A P$ & $O M$ & $M T$ & $I P$ & $P I$ & $P M$ \\
\hline $\boldsymbol{A P}$ & $\begin{array}{llll}1 & 1 & 1 & 1\end{array}$ & $\frac{4}{13} \frac{4}{11} \frac{4}{9} \frac{4}{7}$ & $1 \frac{3}{2} 2 \frac{5}{2}$ & $\frac{7}{4} \frac{9}{4} \frac{11}{4} \frac{13}{4}$ & $1 \frac{3}{2} 2 \frac{5}{2}$ & $\frac{1}{4} \frac{2}{7} \frac{1}{3} \frac{2}{5}$ \\
\hline$O M$ & $\frac{7}{4} \frac{9}{4} \frac{11}{4} \frac{13}{4}$ & $\begin{array}{llll}1 & 1 & 1 & 1\end{array}$ & $\frac{5}{2} 3 \frac{7}{2} 4$ & $\frac{13}{4} \frac{15}{4} \frac{17}{4} \frac{19}{4}$ & $\frac{5}{2} 3 \frac{7}{2} 4$ & $1 \frac{3}{2} 2 \frac{5}{2}$ \\
\hline$M T$ & $\frac{2}{5} \frac{1}{2} \frac{2}{3} 1$ & $\frac{1}{4} \frac{2}{7} \frac{1}{3} \frac{2}{5}$ & $\begin{array}{llll}1 & 1 & 1 & 1\end{array}$ & $1 \frac{3}{2} 2 \frac{5}{2}$ & $1 \frac{3}{2} 2 \frac{5}{2}$ & $\frac{4}{19} \frac{4}{17} \frac{4}{15} \frac{4}{13}$ \\
\hline IP & $\frac{4}{13} \quad \frac{4}{11} \quad \frac{4}{9} \quad \frac{4}{7}$ & $\frac{4}{19} \frac{4}{17} \frac{4}{15} \frac{4}{13}$ & $\frac{2}{5} \frac{1}{2} \frac{2}{3} 1$ & $\begin{array}{llll}1 & 1 & 1 & 1\end{array}$ & $1 \frac{3}{2} \quad 2 \frac{5}{2}$ & $\frac{4}{19} \frac{4}{17} \frac{4}{15} \frac{4}{13}$ \\
\hline$P I$ & $\frac{2}{5} \frac{1}{2} \frac{2}{3} 1$ & $\frac{1}{4} \frac{2}{7} \frac{1}{3} \frac{2}{5}$ & $\frac{2}{5} \frac{1}{2} \frac{2}{3} 1$ & $\frac{2}{5} \frac{1}{2} \frac{2}{3} 1$ & $\begin{array}{llll}1 & 1 & 1 & 1\end{array}$ & $\frac{4}{13} \frac{4}{11} \frac{4}{9} \frac{4}{7}$ \\
\hline$P M$ & $\frac{5}{2} 3 \frac{7}{2} 4$ & $\frac{2}{5} \frac{1}{2} \frac{2}{3} 1$ & $\frac{13}{4} \frac{15}{4} \frac{17}{4} \frac{19}{4}$ & $\frac{13}{4} \frac{15}{4} \frac{17}{4} \frac{19}{4}$ & $\frac{7}{4} \frac{9}{4} \frac{11}{4} \frac{13}{4}$ & $\begin{array}{llll}1 & 1 & 1 & 1\end{array}$ \\
\hline FSE & $\frac{5}{63} \frac{5}{41} \frac{17}{95} \frac{6}{23}$ & $\frac{7}{39} \frac{21}{82} \frac{5}{14} \frac{1}{2}$ & $\frac{3}{52} \frac{7}{79} \frac{5}{38} \frac{12}{61}$ & $\frac{3}{64} \frac{4}{59} \frac{4}{41} \frac{9}{62}$ & $\frac{4}{97} \frac{1}{18} \frac{5}{63} \frac{9}{71}$ & $\frac{2}{11} \frac{1}{4} \frac{31}{90} \frac{11}{23}$ \\
\hline
\end{tabular}

Table B. Pairwise Comparison Matrix for Sub features of Assembly and Disassembly

\begin{tabular}{|c|c|c|c|c|c|}
\hline & & Assembly & Disassen & & \\
\hline & $N C$ & $A P$ & $A C$ & $A M$ & $T A D$ \\
\hline $\boldsymbol{N C}$ & $1 \quad 1 \quad 1 \quad 1$ & $\begin{array}{llll}1 & 2 & 1 & 2\end{array}$ & $\begin{array}{llll}4 & 4 & 4 & 4\end{array}$ & $\begin{array}{llll}4 & 4 & 4 & 4\end{array}$ & 4444 \\
\hline NVe & $\begin{array}{llll}1 & 1 & 1 & 1\end{array}$ & 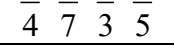 & $\begin{array}{llll}13 & \overline{11} & \overline{9} & \overline{7}\end{array}$ & $\overline{19} \overline{17} \overline{1513}$ & $\overline{1917} \overline{1513}$ \\
\hline D & & 1 & $\begin{array}{llll}4 & 4 & 4 & 4\end{array}$ & 212 & $\begin{array}{llll}1 & 2 & 1 & 2\end{array}$ \\
\hline $\boldsymbol{A T}$ & $\overline{2}^{3} \overline{2}^{4}$ & $\begin{array}{lll}1 & 1 & 1\end{array}$ & $\begin{array}{llll}\overline{13} & \overline{11} & \overline{9} & \overline{7}\end{array}$ & $\overline{5} \overline{2} \overline{3}^{1}$ & $\overline{4} \overline{7} \overline{3} \overline{5}$ \\
\hline$A C$ & $\underline{7} \quad \underline{9} 11 \quad 13$ & $79 \underline{11} 13$ & 11 & $2 \frac{1}{2}$ & $\underline{4} \underline{4} \underline{4}$ \\
\hline & $\begin{array}{llll}\overline{4} & \overline{4} & \overline{4} & \overline{4} \\
\end{array}$ & $\begin{array}{llll}\overline{4} & \overline{4} & \overline{4} & \overline{4} \\
\end{array}$ & & $\overline{5} \overline{2} \overline{3}^{1}$ & $\begin{array}{llll}\overline{13} & \overline{11} & \overline{9} & \overline{7}\end{array}$ \\
\hline$A M$ & 13151719 & 13,5 & 13 & 1 & 1212 \\
\hline & 4444 & 2 & 2 & 1 & $\begin{array}{llll}4 & 7 & 3 & 5 \\
\end{array}$ \\
\hline & 13151719 & $\frac{5}{3}, \frac{7}{4}$ & $7 \quad 9 \quad 11 \quad 13$ & $\frac{5}{3}, \frac{7}{4}$ & \\
\hline & $\overline{4} \overline{4} \overline{4}$ & $\overline{2}^{3} \overline{2}^{4}$ & $\begin{array}{llll}\overline{4} & \overline{4} & \overline{4} & \overline{4} \\
\end{array}$ & $\overline{2}^{3} \overline{2}^{4}$ & $\begin{array}{llll}1 & 1 & 1 & 1\end{array}$ \\
\hline & $\begin{array}{llll}3 & 1 & 2 & 7\end{array}$ & $\begin{array}{llll}2 & 7 & 3 & 11\end{array}$ & 114714 & 51213 & 42747 \\
\hline & 71192979 & 21551746 & 9893145 & $365 \overline{734}$ & 1791912 \\
\hline
\end{tabular}


Table C. Pairwise Comparison Matrix for Sub features of Functionality

\begin{tabular}{|c|c|c|c|c|c|c|}
\hline \multicolumn{7}{|c|}{ Functionality FU } \\
\hline & $S F$ & $F M$ & $S T$ & $M T$ & $T M$ & $L D$ \\
\hline \multirow{2}{*}{$S F$} & \multirow{2}{*}{$\begin{array}{llll}1 & 1 & 1 & 1\end{array}$} & $\begin{array}{llll}7 & 9 & 11 & 13\end{array}$ & 1212 & 13151719 & $\begin{array}{llll}1 & 2 & 1 & 2\end{array}$ & 212 \\
\hline & & $\begin{array}{llll}4 & \overline{4} & \overline{4} & 4 \\
\end{array}$ & $\begin{array}{l}4 \quad \overline{7} \\
\end{array} \overline{5}$ & $\overline{4} 4 \overline{4}$ & $\begin{array}{l}4 \\
\end{array} \overline{3} \quad \overline{5}$ & $5 \overline{2} 3$ \\
\hline \multirow{2}{*}{$F M$} & $\underline{4} \underline{4} \quad \underline{4}$ & \multirow{2}{*}{$\begin{array}{llll}1 & 1 & 1 & 1\end{array}$} & $\begin{array}{llll}4 & 4 & 4 & 4\end{array}$ & $1 \frac{2}{1} \underline{2}$ & $\underline{4} \underline{4} \underline{4} \underline{4}$ & $4 \quad 4 \quad 4 \quad 4$ \\
\hline & $\overline{13} \quad \overline{11} \overline{9} \quad \overline{7}$ & & $\overline{13} \quad \overline{11} \overline{9} \quad \overline{7}$ & 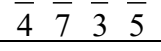 & $\overline{13} \quad \overline{11} \overline{9} \quad \overline{7}$ & 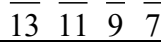 \\
\hline \multirow{2}{*}{$S T$} & $\frac{5}{3}, \frac{7}{4}$ & $7 \quad 9 \quad 11 \quad 13$ & \multirow{2}{*}{$\begin{array}{lllll}1 & 1 & 1 & 1\end{array}$} & 212 & \multirow{2}{*}{$\frac{1}{4} \frac{2}{7} \frac{1}{3} \frac{2}{5}$} & \multirow{2}{*}{$\frac{5}{2} 3 \frac{7}{2} 4$} \\
\hline & $\overline{2}^{5} \overline{2}^{4}$ & 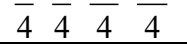 & & $\overline{5} \overline{2} \overline{3}^{1}$ & & \\
\hline \multirow{2}{*}{$M T$} & $\underline{4} \underline{4} \underline{4} \underline{4}$ & $\underline{5}_{3}-\frac{7}{4}$ & \multirow{2}{*}{$1 \frac{3}{2} \quad 2 \frac{5}{2}$} & \multirow{2}{*}{$\begin{array}{llll}1 & 1 & 1 & 1\end{array}$} & $\underline{4} \underline{4} \underline{4} \underline{4}$ & \multirow{2}{*}{$\frac{2}{5} \frac{1}{2} \frac{2}{3} 1$} \\
\hline & $\overline{19} \overline{17} \overline{1513}$ & $2 \quad 2$ & & & $19 \overline{17} \overline{1513}$ & \\
\hline \multirow{2}{*}{$T M$} & $\frac{5}{3} 3 \frac{7}{4}$ & $7 \underline{9} \quad \underline{11} \quad \underline{13}$ & \multirow{2}{*}{$\frac{5}{2} 3 \frac{7}{2} 4$} & 13151719 & \multirow{2}{*}{$\begin{array}{llll}1 & 1 & 1 & 1\end{array}$} & $\begin{array}{llll}7 & 9 & 11 & 13\end{array}$ \\
\hline & 22 & $\begin{array}{llll}4 & \overline{4} & \overline{4} & \overline{4} \\
\end{array}$ & & $\begin{array}{l}444 \\
\end{array}$ & & $\begin{array}{llll}\overline{4} & \overline{4} & \overline{4} & \overline{4} \\
\end{array}$ \\
\hline \multirow{2}{*}{$L D$} & $2 \underline{5}$ & $\underline{7} \underline{9} \underline{11} \underline{13}$ & $\underline{1} \underline{2} \underline{1} \underline{2}$ & $1 \underline{3} 2 \underline{5}$ & $\underline{4} \underline{4} \underline{4} \underline{4}$ & \multirow{2}{*}{$\begin{array}{llll}1 & 1 & 1 & 1\end{array}$} \\
\hline & $2 \quad 2$ & $\begin{array}{llll}4 & 4 & 4 & 4 \\
\end{array}$ & $\begin{array}{llll}4 & 7 & 3 & 5 \\
\end{array}$ & 2 & $\begin{array}{llll}13 & 11 & 9 & 7\end{array}$ & \\
\hline \multirow{2}{*}{ FSE } & $\begin{array}{llll}5 & 5 & 5 & 16\end{array}$ & $\begin{array}{llll}3 & 4 & 5 & 6\end{array}$ & $\begin{array}{llll}1 & 9 & 8 & 1\end{array}$ & 41102 & 16162631 & $\begin{array}{llll}4 & 7 & 3 & 1\end{array}$ \\
\hline & $49 \overline{3626} \overline{61}$ & $\overline{82} \overline{85} \overline{78} \overline{67}$ & $8 \overline{58} \overline{33} \overline{3}$ & $519 \overline{639}$ & $85 \overline{617163}$ & $\overline{5159} \overline{17} \overline{4}$ \\
\hline
\end{tabular}

Table D. Pairwise Comparison Matrix for Sub features of Life Cycle Cost

\begin{tabular}{|c|c|c|c|c|c|}
\hline \multicolumn{6}{|c|}{ Life Cycle Cost LC } \\
\hline & $D A$ & $S R$ & $R C$ & $O C$ & $S C$ \\
\hline$D A$ & $\begin{array}{llll}1 & 1 & 1 & 1\end{array}$ & $\frac{5}{2} 3 \frac{7}{2} 4$ & $\frac{4}{13} \frac{4}{11} \frac{4}{9} \frac{4}{7}$ & $\frac{2}{5} \frac{1}{2} \frac{2}{3} 1$ & $\frac{13}{4} \frac{15}{4} \frac{17}{4} \frac{19}{4}$ \\
\hline$S R$ & $\frac{1}{4} \frac{2}{7} \frac{1}{3} \frac{2}{5}$ & $\begin{array}{llll}1 & 1 & 1 & 1\end{array}$ & $1 \frac{3}{2} 2 \frac{5}{2}$ & $\frac{1}{4} \frac{2}{7} \frac{1}{3} \quad \frac{2}{5}$ & $\frac{1}{4} \frac{2}{7} \frac{1}{3} \frac{2}{5}$ \\
\hline$R C$ & $\frac{7}{4} \frac{9}{4} \frac{11}{4} \frac{13}{4}$ & $\frac{2}{5} \frac{1}{2} \frac{2}{3} 1$ & $\begin{array}{llll}1 & 1 & 1 & 1\end{array}$ & $\frac{4}{19} \frac{4}{17} \frac{4}{15} \frac{4}{13}$ & $\frac{7}{4} \frac{9}{4} \frac{11}{4} \frac{13}{4}$ \\
\hline$O C$ & $1 \frac{3}{2} 2 \frac{5}{2}$ & $\frac{5}{2} 3 \frac{7}{2} 4$ & $\frac{13}{4} \frac{15}{4} \frac{17}{4} \frac{19}{4}$ & $\begin{array}{llll}1 & 1 & 1 & 1\end{array}$ & $\frac{13}{4} \frac{15}{4} \frac{17}{4} \frac{19}{4}$ \\
\hline$S C$ & $\frac{4}{19} \frac{4}{17} \frac{4}{15} \frac{4}{13}$ & $\frac{5}{2} 3 \frac{7}{2} 4$ & $\frac{4}{13} \quad \frac{4}{11} \quad \frac{4}{9} \frac{4}{7}$ & $\frac{4}{19} \frac{4}{17} \frac{4}{15} \frac{4}{13}$ & $\begin{array}{llll}1 & 1 & 1 & 1\end{array}$ \\
\hline FSE & $\frac{9}{58} \frac{20}{97} \frac{26}{95} \frac{10}{27}$ & $\frac{2}{35} \frac{7}{87} \frac{1}{9} \frac{2}{13}$ & $\frac{5}{47} \frac{10}{67} \frac{13}{63} \frac{15}{52}$ & $\frac{11}{48} \frac{14}{45} \frac{5}{12} \frac{5}{9}$ & $\frac{3}{34} \frac{11}{95} \frac{12}{79} \frac{16}{79}$ \\
\hline
\end{tabular}


Table E. Pairwise Comparison Matrix for Sub features of Maintainability

\begin{tabular}{|c|c|c|c|c|c|c|}
\hline \multicolumn{7}{|c|}{ Maintainability MN } \\
\hline & $R M$ & $D M$ & $M C$ & $L P$ & $M F$ & $M S$ \\
\hline $\boldsymbol{R M}$ & $\begin{array}{llll}1 & 1 & 1 & 1\end{array}$ & $\frac{7}{4} \frac{9}{4} \frac{11}{4} \frac{13}{4}$ & $\frac{4}{19} \frac{4}{17} \quad \frac{4}{15} \frac{4}{13}$ & $1 \frac{3}{2} \quad 2 \frac{5}{2}$ & $\frac{4}{19} \frac{4}{17} \frac{4}{15} \frac{4}{13}$ & $\frac{2}{5} \frac{1}{2} \frac{2}{3} 1$ \\
\hline$D M$ & $\frac{4}{13} \frac{4}{11} \frac{4}{9} \frac{4}{7}$ & $\begin{array}{llll}1 & 1 & 1 & 1\end{array}$ & $\frac{1}{4} \frac{2}{7} \frac{1}{3} \frac{2}{5}$ & $\frac{4}{13} \frac{4}{11} \frac{4}{9} \frac{4}{7}$ & $\frac{2}{5} \frac{1}{2} \frac{2}{3} 1$ & $\frac{7}{4} \frac{9}{4} \frac{11}{4} \frac{13}{4}$ \\
\hline MC & $\frac{13}{4} \frac{15}{4} \frac{17}{4} \frac{19}{4}$ & $\frac{5}{2} 3 \frac{7}{2} 4$ & $\begin{array}{llll}1 & 1 & 1 & 1\end{array}$ & $\frac{5}{2} 3 \frac{7}{2} 4$ & $\frac{1}{4} \frac{2}{7} \frac{1}{3} \quad \frac{2}{5}$ & $1 \frac{3}{2} 2 \frac{5}{2}$ \\
\hline $\boldsymbol{L P}$ & $\frac{2}{5} \frac{1}{2} \frac{2}{3} 1$ & $\frac{7}{4} \frac{9}{4} \frac{11}{4} \frac{13}{4}$ & $\frac{1}{4} \frac{2}{7} \frac{1}{3} \frac{2}{5}$ & $\begin{array}{llll}1 & 1 & 1 & 1\end{array}$ & $\frac{7}{4} \frac{9}{4} \frac{11}{4} \frac{13}{4}$ & $\frac{4}{13} \frac{4}{11} \frac{4}{9} \frac{4}{7}$ \\
\hline MF & $\frac{13}{4} \frac{15}{4} \frac{17}{4} \frac{19}{4}$ & $1 \frac{3}{2} 2 \frac{5}{2}$ & $\frac{5}{2} 3 \frac{7}{2} 4$ & $\frac{4}{13} \frac{4}{11} \quad \frac{4}{9} \frac{4}{7}$ & $\begin{array}{llll}1 & 1 & 1 & 1\end{array}$ & $\frac{1}{4} \frac{2}{7} \frac{1}{3} \frac{2}{5}$ \\
\hline$M S$ & $1 \frac{3}{2} 2 \frac{5}{2}$ & $\frac{4}{13} \frac{4}{11} \frac{4}{9} \frac{4}{7}$ & $\frac{2}{5} \frac{1}{2} \frac{2}{3} 1$ & $\frac{7}{4} \frac{9}{4} \frac{11}{4} \frac{13}{4}$ & $\frac{5}{2} 3 \frac{7}{2} 4$ & $\begin{array}{llll}1 & 1 & 1 & 1\end{array}$ \\
\hline & & & & & & \\
\hline & 51144 & 31117 & 1112323 & 47155 & $1 \underline{4} \underline{11} 1$ & 5132013 \\
\hline & $73 \overline{1097 \overline{19}}$ & $\overline{50} \overline{12} \overline{94} \overline{41}$ & $\overline{70} \overline{50} \overline{76} \overline{55}$ & $49 \overline{60} \overline{9121}$ & 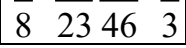 & 48869342 \\
\hline
\end{tabular}

Table F. Pairwise Comparison Matrix for Sub features of Reliability

\begin{tabular}{|c|c|c|c|c|c|}
\hline \multicolumn{6}{|c|}{ Reliability RE } \\
\hline & $\boldsymbol{R F}$ & $\boldsymbol{U L}$ & $D C$ & $R D$ & $R S$ \\
\hline $\boldsymbol{R F}$ & $\begin{array}{llll}1 & 1 & 1 & 1\end{array}$ & $\frac{4}{13} \frac{4}{11} \frac{4}{9} \frac{4}{7}$ & $\frac{5}{2} 3 \frac{7}{2} 4$ & $\frac{13}{4} \frac{15}{4} \frac{17}{4} \frac{19}{4}$ & $\frac{4}{13} \frac{4}{11} \frac{4}{9} \frac{4}{7}$ \\
\hline $\boldsymbol{U} \boldsymbol{L}$ & $\frac{7}{4} \frac{9}{4} \frac{11}{4} \frac{13}{4}$ & $\begin{array}{llll}1 & 1 & 1 & 1\end{array}$ & $\frac{13}{4} \frac{15}{4} \frac{17}{4} \frac{19}{4}$ & $\frac{5}{2} 3 \frac{7}{2} 4$ & $\begin{array}{llll}\frac{1}{4} & \frac{2}{7} & \frac{1}{3} & \frac{2}{5} \\
\end{array}$ \\
\hline$D C$ & $\frac{1}{4} \frac{2}{7} \frac{1}{3} \frac{2}{5}$ & $\frac{4}{19} \frac{4}{17} \frac{4}{15} \frac{4}{13}$ & $\begin{array}{llll}1 & 1 & 1 & 1\end{array}$ & $\frac{7}{4} \frac{9}{4} \frac{11}{4} \frac{13}{4}$ & $\frac{2}{5} \frac{1}{2} \frac{2}{3} 1$ \\
\hline$R D$ & $\frac{4}{19} \frac{4}{17} \frac{4}{15} \frac{4}{13}$ & $\frac{1}{4} \quad \frac{2}{7} \frac{1}{3} \quad \frac{2}{5}$ & $\frac{4}{13} \frac{4}{11} \frac{4}{9} \frac{4}{7}$ & $\begin{array}{llll}1 & 1 & 1 & 1\end{array}$ & $\frac{4}{19} \frac{4}{17} \frac{4}{15} \frac{4}{13}$ \\
\hline$R S$ & $\frac{7}{4} \frac{9}{4} \frac{11}{4} \frac{13}{4}$ & $\frac{5}{2} 3 \frac{7}{2} 4$ & $1 \frac{3}{2} \quad 2 \frac{5}{2}$ & $\frac{13}{4} \frac{15}{4} \frac{17}{4} \frac{19}{4}$ & $\begin{array}{llll}1 & 1 & 1 & 1\end{array}$ \\
\hline FSE & $\frac{7}{46} \frac{1}{5} \frac{5}{19} \frac{22}{63}$ & $\frac{2}{11} \frac{9}{37} \frac{31}{96} \frac{3}{7}$ & $\frac{5}{67} \frac{10}{99} \frac{13}{95} \frac{17}{89}$ & $\frac{2}{49} \frac{1}{20} \frac{1}{16} \frac{1}{12}$ & $\frac{11}{56} \frac{3}{11} \frac{7}{19} \frac{1}{2}$ \\
\hline
\end{tabular}


Table G. Pairwise Comparison Matrix for Sub features of Flexibility

\begin{tabular}{|c|c|c|c|c|c|}
\hline \multicolumn{6}{|c|}{ Flexibility FT } \\
\hline & $C P$ & $S P$ & $S B$ & $\boldsymbol{C U}$ & $M L$ \\
\hline$C P$ & $\begin{array}{llll}1 & 1 & 1 & 1\end{array}$ & $\frac{7}{4} \frac{9}{4} \frac{11}{4} \frac{13}{4}$ & $\frac{2}{5} \frac{1}{2} \frac{2}{3} 1$ & $\frac{5}{2} 3 \frac{7}{2} 4$ & $\frac{2}{5} \frac{1}{2} \frac{2}{3} 1$ \\
\hline$S P$ & $\frac{4}{13} \frac{4}{11} \frac{4}{9} \frac{4}{7}$ & $\begin{array}{llll}1 & 1 & 1 & 1\end{array}$ & $\frac{7}{4} \frac{9}{4} \frac{11}{4} \frac{13}{4}$ & $\frac{13}{4} \frac{15}{4} \frac{17}{4} \frac{19}{4}$ & $\frac{7}{4} \frac{9}{4} \frac{11}{4} \frac{13}{4}$ \\
\hline$S B$ & $1 \frac{3}{2} \quad 2 \frac{5}{2}$ & $\frac{4}{13} \quad \frac{4}{11} \frac{4}{9} \frac{4}{7}$ & $\begin{array}{llll}1 & 1 & 1 & 1\end{array}$ & $\frac{5}{2} 3 \frac{7}{2} 4$ & $\frac{1}{4} \frac{2}{7} \frac{1}{3} \frac{2}{5}$ \\
\hline$C U$ & $\frac{1}{4} \frac{2}{7} \frac{1}{3} \frac{2}{5}$ & $\frac{4}{19} \frac{4}{17} \frac{4}{15} \frac{4}{13}$ & $\frac{1}{4} \frac{2}{7} \frac{1}{3} \frac{2}{5}$ & $\begin{array}{llll}1 & 1 & 1 & 1\end{array}$ & $\frac{4}{13} \frac{4}{11} \frac{4}{9} \frac{4}{7}$ \\
\hline$M L$ & $1 \frac{3}{2} 2 \frac{5}{2}$ & $\frac{4}{13} \frac{4}{11} \frac{4}{9} \frac{4}{7}$ & $\frac{5}{2} 3 \frac{7}{2} 4$ & $\frac{7}{4} \frac{9}{4} \frac{11}{4} \frac{13}{4}$ & $\begin{array}{llll}1 & 1 & 1 & 1\end{array}$ \\
\hline FSE & $\frac{2}{15} \frac{5}{27} \frac{25}{97} \frac{17}{46}$ & $\frac{3}{17} \frac{14}{57} \frac{1}{313} \frac{6}{13}$ & $\frac{1}{9} \frac{11}{70} \frac{7}{32} \frac{11}{36}$ & $\frac{2}{45} \frac{1}{18} \frac{1}{14} \frac{3}{31}$ & $\frac{1}{7} \frac{17}{82} \frac{23}{79} \frac{20}{49}$ \\
\hline
\end{tabular}

Table H. Pairwise Comparison Matrix for Sub features of Operation

\begin{tabular}{|c|c|c|c|c|c|c|}
\hline \multicolumn{7}{|c|}{ Operation OP } \\
\hline & $\boldsymbol{W F}$ & $A S$ & $S L$ & $\boldsymbol{E} \boldsymbol{U}$ & $D T$ & $P M$ \\
\hline \multirow{2}{*}{$\boldsymbol{W F}$} & \multirow{2}{*}{11} & \multirow{2}{*}{$\frac{5}{2} 3 \frac{7}{2} 4$} & $4 \quad 4 \quad 4 \quad 4$ & $12 \leq 12$ & $4 \quad 4 \quad 4 \quad 4$ & $\begin{array}{llll}7 & 9 & 11 & 13\end{array}$ \\
\hline & & & $\begin{array}{llll}13 & 11 & 9 & 7\end{array}$ & $\begin{array}{llll}4 & 7 & 3 & 5 \\
\end{array}$ & $\begin{array}{llll}13 & 11 & 9 & 7\end{array}$ & $\begin{array}{l}4 \quad \overline{4} \\
\end{array}$ \\
\hline \multirow{2}{*}{$A S$} & $\begin{array}{llll}1 & 2 & 1 & 2\end{array}$ & \multirow{2}{*}{$\begin{array}{lll}1 & 1 & 1\end{array}$} & $1 \underline{3}, \frac{5}{2}$ & $\begin{array}{llll}4 & 4 & 4 & 4\end{array}$ & $1315 \quad 1719$ & \multirow{2}{*}{$1 \frac{3}{2} 2 \frac{5}{2}$} \\
\hline & 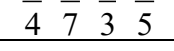 & & $1 \overline{2}$ & $\overline{19} \overline{17} \overline{1513}$ & $\begin{array}{llll}4 & 4 & 4 \\
\end{array}$ & \\
\hline \multirow{2}{*}{ S } & $\begin{array}{llll}7 & 9 & 11 & 13\end{array}$ & 212 & \multirow{2}{*}{$\begin{array}{llll}1 & 1 & 1 & 1\end{array}$} & 212 & \multirow{2}{*}{$1 \frac{3}{2} 2 \frac{5}{2}$} & $\begin{array}{llll}7 & 9 & 11 & 13\end{array}$ \\
\hline & 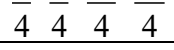 & $\overline{5} \overline{2} \overline{3}^{1}$ & & $\overline{5} \overline{2} \overline{3}^{1}$ & & $\overline{4} \overline{4} \overline{4}$ \\
\hline \multirow{2}{*}{$\boldsymbol{E U}$} & \multirow{2}{*}{$\frac{5}{2} 3 \frac{7}{2} 4$} & $1315 \quad 1719$ & \multirow{2}{*}{$1 \frac{3}{2} 2 \frac{5}{2}$} & \multirow{2}{*}{$\begin{array}{llll}1 & 1 & 1 & 1\end{array}$} & $\begin{array}{llll}7 & 9 & 11 & 13\end{array}$ & $1315 \quad 1719$ \\
\hline & & $\begin{array}{llll}4 & 4 & 4 & 4 \\
\end{array}$ & & & $\begin{array}{llll}\overline{4} & \overline{4} & \overline{4} & \overline{4} \\
\end{array}$ & $\begin{array}{llll}4 & 4 & 4 & 4 \\
\end{array}$ \\
\hline \multirow{2}{*}{$D T$} & 구의 11 13 & 4444 & $\underline{2}-1$ & $\underline{4} \underline{4} \underline{4} \underline{4}$ & \multirow{2}{*}{$\begin{array}{llll}1 & 1 & 1 & 1\end{array}$} & \multirow{2}{*}{$\frac{2}{5} \frac{1}{2} \frac{2}{3} 1$} \\
\hline & $\begin{array}{llll}\overline{4} & \overline{4} & \overline{4} & \overline{4} \\
\end{array}$ & $\overline{19} \overline{17} \quad \overline{1513}$ & $\overline{5} \overline{2} \overline{3}^{1}$ & $\begin{array}{llll}\overline{13} & \overline{11} & \overline{9} & \overline{7}\end{array}$ & & \\
\hline \multirow{2}{*}{$P M$} & $4 \quad 4 \quad 4 \quad 4$ & $\underline{2} 1 \underline{2}$ & $4 \quad 4 \quad 4 \quad 4$ & $44 \quad 4 \quad 4$ & \multirow{2}{*}{$1 \frac{3}{2} 2 \frac{5}{2}$} & \multirow{2}{*}{$\begin{array}{llll}1 & 1 & 1 & 1\end{array}$} \\
\hline & 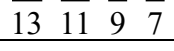 & 523 & $\begin{array}{llll}\overline{13} & \overline{11} & \overline{9} & \overline{7}\end{array}$ & $1917 \quad 1513$ & & \\
\hline & 99 & $\begin{array}{llll}1 & 6 & 6 & 12 \\
\end{array}$ & $\begin{array}{llll}7 & 11919 \\
\end{array}$ & 9172215 & $\begin{array}{llll}3 & 3 & 5 & 2\end{array}$ & $\begin{array}{llll}3 & 4 & 8 & 12\end{array}$ \\
\hline & $9870 \quad 734$ & 10412941 & 7479262 & 47635929 & 49354111 & 62577979 \\
\hline
\end{tabular}


APPENDIX II

Table I. Fuzzified Pugh Matrix for Manufacturing using all design concept as baseline

\begin{tabular}{|c|c|c|c|c|}
\hline \multirow{2}{*}{\begin{tabular}{|c|} 
Sub \\
features \\
of MA
\end{tabular}} & \multicolumn{4}{|c|}{ Design Concepts } \\
\hline & Concept 1 & Concept 2 & Concept 3 & Concept 4 \\
\hline \multirow{6}{*}{$\begin{array}{c}\text { AP } \\
\text { OM } \\
\text { MT } \\
\text { IP } \\
\text { PI } \\
\text { PM }\end{array}$} & $\begin{array}{llll}1 & 1 & 1 & 1\end{array}$ & $\begin{array}{llll}3 / 4 & 15 / 4 & 17 / 4 & 19 / 4\end{array}$ & $\begin{array}{llll}5 / 2 & 3 & 7 / 2 & 4\end{array}$ & $\begin{array}{ll}1 & 1\end{array}$ \\
\hline & $\begin{array}{llll}1 & 1 & 1 & 1\end{array}$ & $\begin{array}{llll}7 / 4 & 9 / 4 & 11 / 4 & 13 / 4\end{array}$ & $\begin{array}{llll}1 & 3 / 2 & 2 & 5 / 2\end{array}$ & $\begin{array}{llll}5 / 2 & 3 & 7 / 2 & 4\end{array}$ \\
\hline & $\begin{array}{llll}1 & 1 & 1 & 1\end{array}$ & $\begin{array}{llll}7 / 4 & 9 / 4 & 11 / 4 & 13 / 4\end{array}$ & $\begin{array}{llll}13 / 4 & 15 / 4 & 17 / 4 & 19 / 4\end{array}$ & $\begin{array}{llll}13 / 4 & 15 / 4 & 17 / 4 & 19 / 4\end{array}$ \\
\hline & $\begin{array}{llll}1 & 1 & 1 & 1\end{array}$ & $\begin{array}{llll}13 / 4 & 15 / 4 & 17 / 4 & 19 / 4\end{array}$ & $\begin{array}{llll}5 / 2 & 3 & 7 / 2 & 4\end{array}$ & $\begin{array}{llll}5 / 2 & 3 & 7 / 2 & 4\end{array}$ \\
\hline & $\begin{array}{llll}1 & 1 & 1 & 1\end{array}$ & $\begin{array}{llll}5 / 2 & 3 & 7 / 2 & 4\end{array}$ & $\begin{array}{llll}13 / 4 & 15 / 4 & 17 / 4 & 19 / 4\end{array}$ & $\begin{array}{llll}7 / 4 & 9 / 4 & 11 / 4 & 13 / 4\end{array}$ \\
\hline & $\begin{array}{llll}1 & 1 & 1 & 1\end{array}$ & $\begin{array}{llll}13 / 4 & 15 / 4 & 17 / 4 & 19 / 4\end{array}$ & $\begin{array}{llll}13 / 4 & 15 / 4 & 17 / 4 & 19 / 4\end{array}$ & $\begin{array}{llll}5 / 2 & 3 & 7 / 2 & 4\end{array}$ \\
\hline \multirow{6}{*}{$\begin{array}{c}\text { AP } \\
\text { OM } \\
\text { MT } \\
\text { IP } \\
\text { PI } \\
\text { PM }\end{array}$} & $\begin{array}{llll}1 & 3 / 2 & 2 & 5 / 2\end{array}$ & $\begin{array}{llllll} & 1 & 1 & 1 & 1\end{array}$ & $\begin{array}{llll}7 / 4 & 9 / 4 & 11 / 4 & 13 / 4\end{array}$ & $\begin{array}{llll}1 & 3 / 2 & 2 & 5 / 2\end{array}$ \\
\hline & $\begin{array}{llll}5 / 2 & 3 & 7 / 2 & 4\end{array}$ & 11 & $\begin{array}{llll}1 & 3 / 2 & 2 & 5 / 2\end{array}$ & $13 / 4 \quad 15 / 4 \quad 17 / 4 \quad 19 / 4$ \\
\hline & $\begin{array}{llll}5 / 2 & 3 & 7 / 2 & 4\end{array}$ & $\begin{array}{ll}1 & 1\end{array}$ & $\begin{array}{llll}5 / 2 & 3 & 7 / 2 & 4\end{array}$ & $\begin{array}{llll}5 / 2 & 3 & 7 / 2 & 4\end{array}$ \\
\hline & $\begin{array}{llll}1 & 3 / 2 & 2 & 5 / 2\end{array}$ & $\begin{array}{ll}1 & 1\end{array}$ & $\begin{array}{llll}7 / 4 & 9 / 4 & 11 / 4 & 13 / 4\end{array}$ & $\begin{array}{llll}7 / 4 & 9 / 4 & 11 / 4 & 13 / 4\end{array}$ \\
\hline & $\begin{array}{llll}7 / 4 & 9 / 4 & 11 / 4 & 13 / 4\end{array}$ & $\begin{array}{lll}1 & 1 & 1\end{array}$ & $\begin{array}{llll}5 / 2 & 3 & 7 / 2 & 4\end{array}$ & $\begin{array}{llll}1 & 3 / 2 & 2 & 5 / 2\end{array}$ \\
\hline & $\begin{array}{llll}1 & 3 / 2 & 2 & 5 / 2\end{array}$ & $\begin{array}{lll}1 & 1 & 1\end{array}$ & $\begin{array}{llll}1 & 1 & 1 & 1 \\
\end{array}$ & $\begin{array}{llll}7 / 4 & 9 / 4 & 11 / 4 & 13 / 4\end{array}$ \\
\hline \multirow{6}{*}{\begin{tabular}{|c|} 
AP \\
OM \\
MT \\
IP \\
PI \\
PM
\end{tabular}} & \begin{tabular}{llll|}
$7 / 4$ & $9 / 4$ & $11 / 4$ & $13 / 4$ \\
\end{tabular} & $\begin{array}{llll}5 / 2 & 3 & 7 / 2 & 4 \\
\end{array}$ & \begin{tabular}{lll|}
1 & 1 & 1 \\
\end{tabular} & $\begin{array}{llll}7 / 4 & 9 / 4 & 11 / 4 & 13 / 4 \\
\end{array}$ \\
\hline & $\begin{array}{|llll|}13 / 4 & 15 / 4 & 17 / 4 & 19 / 4 \\
\end{array}$ & $\begin{array}{llll}7 / 4 & 9 / 4 & 11 / 4 & 13 / 4\end{array}$ & $\begin{array}{lll}1 & 1 & 1\end{array}$ & $13 / 4 \quad 15 / 4 \quad 17 / 4 \quad 19 / 4$ \\
\hline & $\begin{array}{|llll|}1 & 3 / 2 & 2 & 5 / 2 \\
\end{array}$ & $\begin{array}{llll}7 / 4 & 9 / 4 & 11 / 4 & 13 / 4 \\
\end{array}$ & \begin{tabular}{llll|}
1 & 1 & 1 & 1 \\
\end{tabular} & $\begin{array}{lllll}1 & 1 & 1 & 1 \\
\end{array}$ \\
\hline & $\begin{array}{llll}7 / 4 & 9 / 4 & 11 / 4 & 13 / 4\end{array}$ & $\begin{array}{llll}5 / 2 & 3 & 7 / 2 & 4\end{array}$ & $\begin{array}{lll}1 & 1 & 1 \\
\end{array}$ & $\begin{array}{llll}1 & 1 & 1 & 1 \\
\end{array}$ \\
\hline & $\begin{array}{llll}1 & 3 / 2 & 2 & 5 / 2\end{array}$ & $\begin{array}{llll}5 / 2 & 3 & 7 / 2 & 4\end{array}$ & $\begin{array}{lll}1 & 1 & 1\end{array}$ & $\begin{array}{llll}7 / 4 & 9 / 4 & 11 / 4 & 13 / 4\end{array}$ \\
\hline & $\begin{array}{llll}1 & 3 / 2 & 2 & 5 / 2\end{array}$ & $\begin{array}{lll}1 & 1 & 1\end{array}$ & $\begin{array}{lll}1 & 1 & 1\end{array}$ & $\begin{array}{llll}5 / 2 & 3 & 7 / 2 & 4\end{array}$ \\
\hline \multirow{6}{*}{$\begin{array}{c}\text { AP } \\
\text { OM } \\
\text { MT } \\
\text { IP } \\
\text { PI } \\
\text { PM }\end{array}$} & $\begin{array}{llll}1 & 1 & 1 & 1 \\
\end{array}$ & $\begin{array}{llll}13 / 4 & 15 / 4 & 17 / 4 & 19 / 4\end{array}$ & $\begin{array}{llll}5 / 2 & 3 & 7 / 2 & 4\end{array}$ & $\begin{array}{lll}1 & 1 & 1\end{array}$ \\
\hline & $\begin{array}{llll}7 / 4 & 9 / 4 & 11 / 4 & 13 / 4\end{array}$ & $\begin{array}{llll}7 / 4 & 9 / 4 & 11 / 4 & 13 / 4 \\
\end{array}$ & $\begin{array}{llll}7 / 4 & 9 / 4 & 11 / 4 & 13 / 4\end{array}$ & $\begin{array}{lll}1 & 1 & 1\end{array}$ \\
\hline & $\begin{array}{llll}1 & 3 / 2 & 2 & 5 / 2 \\
\end{array}$ & $\begin{array}{llll}1 & 3 / 2 & 2 & 5 / 2 \\
\end{array}$ & \begin{tabular}{llll|}
1 & 1 & 1 & 1 \\
\end{tabular} & $\begin{array}{lll}1 & 1 & 1 \\
\end{array}$ \\
\hline & $\begin{array}{llll}7 / 4 & 9 / 4 & 11 / 4 & 13 / 4\end{array}$ & $\begin{array}{llll}5 / 2 & 3 & 7 / 2 & 4\end{array}$ & $\begin{array}{llll}1 & 1 & 1 & 1 \\
\end{array}$ & $\begin{array}{lll}1 & 1 & 1\end{array}$ \\
\hline & $\begin{array}{llll}5 / 2 & 3 & 7 / 2 & 4\end{array}$ & $\begin{array}{llll}5 / 2 & 3 & 7 / 2 & 4\end{array}$ & $\begin{array}{llll}13 / 4 & 15 / 4 & 17 / 4 & 19 / 4\end{array}$ & $\begin{array}{lll}1 & 1 & 1\end{array}$ \\
\hline & $\begin{array}{llll}7 / 4 & 9 / 4 & 11 / 4 & 13 / 4 \\
\end{array}$ & $\begin{array}{llll}5 / 2 & 3 & 7 / 2 & 4 \\
\end{array}$ & $\begin{array}{llll}5 / 2 & 3 & 7 / 2 & 4 \\
\end{array}$ & $\begin{array}{llll}1 & 1 & 1 & 1 \\
\end{array}$ \\
\hline \multirow{2}{*}{ Agg } & $\begin{array}{llll}47 & 155 & 239 & 31 \\
\end{array}$ & $115 \quad 53 \quad 88 \quad 245$ & $165 \quad 305 \quad 148 \quad 419$ & $\begin{array}{llll}39 & 256 & 307 & 911\end{array}$ \\
\hline & $\begin{array}{llll}52 & 94 & 77 & 5\end{array}$ & $\overline{63} \quad \overline{16} \quad \overline{15}$ & $\overline{98} \quad \overline{99} \quad \overline{27}$ & $\begin{array}{llll}23 & 83 & 56 & 91\end{array}$ \\
\hline
\end{tabular}


Table J. Fuzzified Pugh matrix for Assembly and Disassembly using all design concept as baseline

\begin{tabular}{|c|c|c|c|c|}
\hline \multirow{2}{*}{\begin{tabular}{|c} 
Sub \\
features \\
of $\mathrm{AD}$ \\
\end{tabular}} & \multicolumn{4}{|c|}{ Design Concepts } \\
\hline & Concept 1 & Concept 2 & Concept 3 & Concept 4 \\
\hline \multirow{5}{*}{\begin{tabular}{|c|}
$\mathrm{NC}$ \\
$\mathrm{AP}$ \\
$\mathrm{AC}$ \\
$\mathrm{AM}$ \\
$\mathrm{TAD}$ \\
\end{tabular}} & $\begin{array}{llll}1 & 1 & 1 & 1\end{array}$ & $\begin{array}{llll}5 / 2 & 3 & 7 / 2 & 4\end{array}$ & $\begin{array}{llll}5 / 2 & 3 & 7 / 2 & 4\end{array}$ & \begin{tabular}{|llll}
$13 / 4$ & $15 / 4$ & $17 / 4$ & $19 / 4$
\end{tabular} \\
\hline & $\begin{array}{llll}1 & 1 & 1 & 1\end{array}$ & $\begin{array}{llll}5 / 2 & 3 & 7 / 2 & 4\end{array}$ & $\begin{array}{llll}7 / 4 & 9 / 4 & 11 / 4 & 13 / 4\end{array}$ & $\begin{array}{llll}5 / 2 & 3 & 7 / 2 & 4\end{array}$ \\
\hline & $\begin{array}{llll}1 & 1 & 1 & 1\end{array}$ & $13 / 4 \quad 15 / 4 \quad 17 / 4 \quad 19 / 4$ & $\begin{array}{llll}7 / 4 & 9 / 4 & 11 / 4 & 13 / 4\end{array}$ & $\begin{array}{llll}1 & 3 / 2 & 2 & 5 / 2\end{array}$ \\
\hline & $\begin{array}{llll}1 & 1 & 1 & 1\end{array}$ & 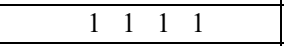 & $\begin{array}{lllll}1 & 1 & 1 & 1 \\
\end{array}$ & $\begin{array}{llll}5 / 2 & 3 & 7 / 2 & 4 \\
\end{array}$ \\
\hline & $\begin{array}{llll}1 & 1 & 1 & 1 \\
\end{array}$ & $\begin{array}{llll}5 / 2 & 3 & 7 / 2 & 4 \\
\end{array}$ & $\begin{array}{llll}1 & 1 & 1 & 1 \\
\end{array}$ & \begin{tabular}{|llll}
$13 / 4$ & $15 / 4$ & $17 / 4$ & $19 / 4$ \\
\end{tabular} \\
\hline \multirow{5}{*}{$\begin{array}{l}\mathrm{NC} \\
\mathrm{AP} \\
\mathrm{AC} \\
\mathrm{AM} \\
\mathrm{TAD}\end{array}$} & $\begin{array}{llll}7 / 4 & 9 / 4 & 11 / 4 & 13 / 4 \\
\end{array}$ & $\begin{array}{llll} & 1 & 1 & 1 \\
\end{array}$ & 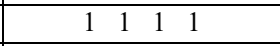 & \begin{tabular}{|llll}
$5 / 2$ & 3 & $7 / 2$ & 4 \\
\end{tabular} \\
\hline & $\begin{array}{llll}7 / 4 & 9 / 4 & 11 / 4 & 13 / 4 \\
\end{array}$ & \begin{tabular}{llll|}
1 & 1 & 1 & 1 \\
\end{tabular} & $\begin{array}{llll}1 & 3 / 2 & 2 & 5 / 2 \\
\end{array}$ & $\begin{array}{llll}1 & 1 & 1 & 1 \\
\end{array}$ \\
\hline & $\begin{array}{llll}1 & 3 / 2 & 2 & 5 / 2\end{array}$ & $\begin{array}{llll}1 & 1 & 1 & 1\end{array}$ & $\begin{array}{llll}1 & 3 / 2 & 2 & 5 / 2\end{array}$ & $\begin{array}{llll}1 & 3 / 2 & 2 & 5 / 2\end{array}$ \\
\hline & $\begin{array}{llll} & 1 & 1 & 1\end{array}$ & $\begin{array}{lll} & 1 & 1\end{array}$ & $\begin{array}{llll}1 & 1 & 1 & 1\end{array}$ & $\begin{array}{llll}5 / 2 & 3 & 7 / 2 & 4\end{array}$ \\
\hline & $\begin{array}{llll}7 / 4 & 9 / 4 & 11 / 4 & 13 / 4 \\
\end{array}$ & $\begin{array}{llll}1 & 1 & 1 & 1\end{array}$ & $\begin{array}{llll}7 / 4 & 9 / 4 & 11 / 4 & 13 / 4\end{array}$ & $\begin{array}{llll}5 / 2 & 3 & 7 / 2 & 4\end{array}$ \\
\hline \multirow{5}{*}{$\begin{array}{c}\mathrm{NC} \\
\mathrm{AP} \\
\mathrm{AC} \\
\mathrm{AM} \\
\mathrm{TAD}\end{array}$} & $\begin{array}{llll}1 & 3 / 2 & 2 & 5 / 2 \\
\end{array}$ & $\begin{array}{llll}7 / 4 & 9 / 4 & 11 / 4 & 13 / 4 \\
\end{array}$ & $\begin{array}{lllll}1 & 1 & 1 & 1 \\
\end{array}$ & $\begin{array}{llll}5 / 2 & 3 & 7 / 2 & 4 \\
\end{array}$ \\
\hline & $\begin{array}{|llll|}7 / 4 & 9 / 4 & 11 / 4 & 13 / 4 \\
\end{array}$ & $\begin{array}{lllll} & 1 & 1 & 1 & 1 \\
\end{array}$ & $\begin{array}{llll} & 1 & 1 & 1\end{array}$ & $\begin{array}{llll}7 / 4 & 9 / 4 & 11 / 4 & 13 / 4\end{array}$ \\
\hline & \begin{tabular}{|llll}
$13 / 4$ & $15 / 4$ & $17 / 4$ & $19 / 4$ \\
\end{tabular} & $\begin{array}{llll}13 / 4 & 15 / 4 & 17 / 4 & 19 / 4 \\
\end{array}$ & \begin{tabular}{llll|}
1 & 1 & 1 & 1 \\
\end{tabular} & $\begin{array}{llll}7 / 4 & 9 / 4 & 11 / 4 & 13 / 4 \\
\end{array}$ \\
\hline & $\begin{array}{|llll|}7 / 4 & 9 / 4 & 11 / 4 & 13 / 4 \\
\end{array}$ & \begin{tabular}{llll|}
$7 / 4$ & $9 / 4$ & $11 / 4$ & $13 / 4$ \\
\end{tabular} & $\begin{array}{llll}1 & 1 & 1 & 1 \\
\end{array}$ & $\begin{array}{llll}7 / 4 & 9 / 4 & 11 / 4 & 13 / 4 \\
\end{array}$ \\
\hline & $\begin{array}{llll}1 & 3 / 2 & 2 & 5 / 2 \\
\end{array}$ & $\begin{array}{llll}7 / 4 & 9 / 4 & 11 / 4 & 13 / 4 \\
\end{array}$ & $\begin{array}{llll}1 & 1 & 1 & 1 \\
\end{array}$ & $\begin{array}{llll}1 & 3 / 2 & 2 & 5 / 2 \\
\end{array}$ \\
\hline \multirow{5}{*}{$\begin{array}{c}\mathrm{NC} \\
\mathrm{AP} \\
\mathrm{AC} \\
\mathrm{AM} \\
\mathrm{TAD}\end{array}$} & $\begin{array}{llll}7 / 4 & 9 / 4 & 11 / 4 & 13 / 4 \\
\end{array}$ & $\begin{array}{llll}1 & 1 & 1 & 1 \\
\end{array}$ & $\begin{array}{llll}5 / 2 & 3 & 7 / 2 & 4 \\
\end{array}$ & 11 \\
\hline & $\begin{array}{llll}5 / 2 & 3 & 7 / 2 & 4\end{array}$ & $\begin{array}{llll}5 / 2 & 3 & 7 / 2 & 4\end{array}$ & $\begin{array}{llll}5 / 2 & 3 & 7 / 2 & 4\end{array}$ & 11 \\
\hline & $\begin{array}{llll}5 / 2 & 3 & 7 / 2 & 4 \\
\end{array}$ & $\begin{array}{llll}13 / 4 & 15 / 4 & 17 / 4 & 19 / 4 \\
\end{array}$ & $\begin{array}{llll}7 / 4 & 9 / 4 & 11 / 4 & 13 / 4 \\
\end{array}$ & \begin{tabular}{llll|}
1 & 1 & 1 & 1 \\
\end{tabular} \\
\hline & $\begin{array}{llll}1 & 1 & 1 & 1 \\
\end{array}$ & $\begin{array}{lllll} & 1 & 1 & 1 & 1 \\
\end{array}$ & $\begin{array}{llll}5 / 2 & 3 & 7 / 2 & 4 \\
\end{array}$ & $\begin{array}{llll}1 & 1 & 1 & 1 \\
\end{array}$ \\
\hline & \begin{tabular}{llll|}
1 & 1 & 1 & 1 \\
\end{tabular} & $\begin{array}{llll}5 / 2 & 3 & 7 / 2 & 4 \\
\end{array}$ & $\begin{array}{|llll|}13 / 4 & 15 / 4 & 17 / 4 & 19 / 4 \\
\end{array}$ & \begin{tabular}{llll|}
1 & 1 & 1 & 1 \\
\end{tabular} \\
\hline \multirow{2}{*}{ Agg } & $\begin{array}{llll}5 & 25 & 178 & 213 \\
\end{array}$ & $1 \quad 73 \quad 226 \quad 541$ & $22 \quad 22 \quad 110 \quad 340$ & $\begin{array}{llll}49 & 44 & 262 \quad 44\end{array}$ \\
\hline & $\begin{array}{llll}13 & 28 & 85 & 47\end{array}$ & $\begin{array}{llll}2 & 65 & 87 & 98\end{array}$ & $63 \quad \overline{27} \quad \overline{57}$ & $\begin{array}{lll}88 & 35 & 89\end{array}$ \\
\hline
\end{tabular}


Table K. Fuzzified Pugh Matrix for Functionality using all design concept as baseline

\begin{tabular}{|c|c|c|c|c|}
\hline \multirow{2}{*}{\begin{tabular}{|c|}
$\begin{array}{c}\text { Sub } \\
\text { features } \\
\text { of FU }\end{array}$ \\
\end{tabular}} & \multicolumn{4}{|c|}{ Design Concepts } \\
\hline & Concept 1 & Concept 2 & Concept 3 & Concept 4 \\
\hline SF & \begin{tabular}{llll|}
1 & 1 & 1 & 1
\end{tabular} & $\begin{array}{llll}1 & 3 / 2 & 2 & 5 / 2\end{array}$ & $\begin{array}{llll}7 / 4 & 9 / 4 & 11 / 4 & 13 / 4\end{array}$ & $\begin{array}{llll}13 / 4 & 15 / 4 & 17 / 4 & 19 / 4\end{array}$ \\
\hline FM & $\begin{array}{llll}1 & 1 & 1 & 1\end{array}$ & $\begin{array}{llll}1 & 3 / 2 & 2 & 5 / 2\end{array}$ & $\begin{array}{llll}7 / 4 & 9 / 4 & 11 / 4 & 13 / 4\end{array}$ & $\begin{array}{llll}5 / 2 & 3 & 7 / 2 & 4\end{array}$ \\
\hline ST & \begin{tabular}{llll|}
1 & 1 & 1 & 1
\end{tabular} & $\begin{array}{llll}7 / 4 & 9 / 4 & 11 / 4 & 13 / 4\end{array}$ & $\begin{array}{llll}13 / 4 & 15 / 4 & 17 / 4 & 19 / 4\end{array}$ & $\begin{array}{llll}5 / 2 & 3 & 7 / 2 & 4\end{array}$ \\
\hline MT & $\begin{array}{llll}1 & 1 & 1 & 1\end{array}$ & $\begin{array}{llll}5 / 2 & 3 & 7 / 2 & 4\end{array}$ & $\begin{array}{llll}5 / 2 & 3 & 7 / 2 & 4\end{array}$ & $\begin{array}{llll}13 / 4 & 15 / 4 & 17 / 4 & 19 / 4\end{array}$ \\
\hline TM & $\begin{array}{llll}1 & 1 & 1 & 1\end{array}$ & $\begin{array}{llll}7 / 4 & 9 / 4 & 11 / 4 & 13 / 4\end{array}$ & $\begin{array}{llll}13 / 4 & 15 / 4 & 17 / 4 & 19 / 4\end{array}$ & $\begin{array}{llll}13 / 4 & 15 / 4 & 17 / 4 & 19 / 4\end{array}$ \\
\hline LD & $\begin{array}{llll}1 & 1 & 1 & 1\end{array}$ & $\begin{array}{lllll} & 1 & 1 & 1 & 1\end{array}$ & $\begin{array}{lllll} & 1 & 1 & 1 & 1\end{array}$ & $\begin{array}{lllll} & 1 & 1 & 1 & 1\end{array}$ \\
\hline SF & $\begin{array}{llll}1 & 3 / 2 & 2 & 5 / 2\end{array}$ & $\begin{array}{llll}1 & 1 & 1 & 1\end{array}$ & $\begin{array}{llll}1 & 3 / 2 & 2 & 5 / 2 \\
\end{array}$ & $\begin{array}{llll}1 & 3 / 2 & 2 & 5 / 2\end{array}$ \\
\hline FM & $\begin{array}{llll}7 / 4 & 9 / 4 & 11 / 4 & 13 / 4\end{array}$ & $\begin{array}{llll}1 & 1 & 1 & 1\end{array}$ & $\begin{array}{llll}1 & 3 / 2 & 2 & 5 / 2\end{array}$ & $\begin{array}{llll}1 & 3 / 2 & 2 & 5 / 2\end{array}$ \\
\hline ST & $\begin{array}{llll}1 & 3 / 2 & 2 & 5 / 2\end{array}$ & $\begin{array}{llll}1 & 1 & 1 & 1\end{array}$ & $\begin{array}{llll}5 / 2 & 3 & 7 / 2 & 4\end{array}$ & $\begin{array}{llll}1 & 3 / 2 & 2 & 5 / 2\end{array}$ \\
\hline MT & $\begin{array}{llll}1 & 3 / 2 & 2 & 5 / 2\end{array}$ & \begin{tabular}{llll|}
1 & 1 & 1 & 1
\end{tabular} & \begin{tabular}{llll|}
$7 / 4$ & $9 / 4$ & $11 / 4$ & $13 / 4$
\end{tabular} & $\begin{array}{llll}7 / 4 & 9 / 4 & 11 / 4 & 13 / 4\end{array}$ \\
\hline TM & $\begin{array}{llll}1 & 3 / 2 & 2 & 5 / 2 \\
\end{array}$ & $\begin{array}{llll}1 & 1 & 1 & 1\end{array}$ & $\begin{array}{lllll} & 1 & 1 & 1 & 1 \\
\end{array}$ & $\begin{array}{llll}1 & 3 / 2 & 2 & 5 / 2\end{array}$ \\
\hline LD & $\begin{array}{llll}1 & 1 & 1 & 1\end{array}$ & $\begin{array}{llll}1 & 1 & 1 & 1\end{array}$ & $\begin{array}{llll}1 & 1 & 1 & 1\end{array}$ & $\begin{array}{llll}1 & 1 & 1 & 1\end{array}$ \\
\hline SF & $\begin{array}{llll}5 / 2 & 3 & 7 / 2 & 4\end{array}$ & $\begin{array}{llll}7 / 4 & 9 / 4 & 11 / 4 & 13 / 4\end{array}$ & $\begin{array}{llll}1 & 1 & 1 & 1\end{array}$ & \begin{tabular}{|llll}
$13 / 4$ & $15 / 4$ & $17 / 4$ & $19 / 4$
\end{tabular} \\
\hline FM & $\begin{array}{llll}5 / 2 & 3 & 7 / 2 & 4\end{array}$ & $\begin{array}{llll}7 / 4 & 9 / 4 & 11 / 4 & 13 / 4\end{array}$ & $\begin{array}{llll}1 & 1 & 1 & 1\end{array}$ & \begin{tabular}{llll|}
$5 / 2$ & 3 & $7 / 2$ & 4
\end{tabular} \\
\hline ST & $\begin{array}{llll}1 & 3 / 2 & 2 & 5 / 2\end{array}$ & $\begin{array}{llll}1 & 3 / 2 & 2 & 5 / 2\end{array}$ & $\begin{array}{llll}1 & 1 & 1 & 1\end{array}$ & $\begin{array}{llll}7 / 4 & 9 / 4 & 11 / 4 & 13 / 4\end{array}$ \\
\hline MT & $\begin{array}{llll}7 / 4 & 9 / 4 & 11 / 4 & 13 / 4\end{array}$ & $\begin{array}{llll}1 & 1 & 1 & 1\end{array}$ & $\begin{array}{llll}1 & 1 & 1 & 1\end{array}$ & $\begin{array}{llll}5 / 2 & 3 & 7 / 2 & 4\end{array}$ \\
\hline TM & $\begin{array}{llll}1 & 3 / 2 & 2 & 5 / 2\end{array}$ & $\begin{array}{llll}1 & 3 / 2 & 2 & 5 / 2\end{array}$ & $\begin{array}{llll}1 & 1 & 1 & 1\end{array}$ & $\begin{array}{llll}1 & 1 & 1 & 1\end{array}$ \\
\hline LD & $\begin{array}{llll}1 & 1 & 1 & 1\end{array}$ & $\begin{array}{lllll} & 1 & 1 & 1 & 1\end{array}$ & $\begin{array}{llll}1 & 1 & 1 & 1\end{array}$ & $\begin{array}{llll}1 & 1 & 1 & 1\end{array}$ \\
\hline SF & $\begin{array}{llll}13 / 4 & 15 / 4 & 17 / 4 & 19 / 4\end{array}$ & \begin{tabular}{llll|}
$13 / 4$ & $15 / 4$ & $17 / 4$ & $19 / 4$
\end{tabular} & $\begin{array}{llll}7 / 4 & 9 / 4 & 11 / 4 & 13 / 4\end{array}$ & \begin{tabular}{llll|}
1 & 1 & 1 & 1
\end{tabular} \\
\hline FM & $\begin{array}{llll}13 / 4 & 15 / 4 & 17 / 4 & 19 / 4\end{array}$ & $\begin{array}{llll}5 / 2 & 3 & 7 / 2 & 4\end{array}$ & $\begin{array}{llll}7 / 4 & 9 / 4 & 11 / 4 & 13 / 4\end{array}$ & $\begin{array}{llll}1 & 1 & 1 & 1\end{array}$ \\
\hline ST & $\begin{array}{llll}5 / 2 & 3 & 7 / 2 & 4\end{array}$ & $\begin{array}{llll}13 / 4 & 15 / 4 & 17 / 4 & 19 / 4\end{array}$ & \begin{tabular}{|llll}
$13 / 4$ & $15 / 4$ & $17 / 4$ & $19 / 4$
\end{tabular} & $\begin{array}{llll}1 & 1 & 1 & 1\end{array}$ \\
\hline MT & $\begin{array}{llll}7 / 4 & 9 / 4 & 11 / 4 & 13 / 4\end{array}$ & $\begin{array}{llll}5 / 2 & 3 & 7 / 2 & 4\end{array}$ & $\begin{array}{llllll} & 1 & 1 & 1 & 1 \\
\end{array}$ & $\begin{array}{llll}1 & 1 & 1 & 1\end{array}$ \\
\hline TM & $\begin{array}{llll}5 / 2 & 3 & 7 / 2 & 4\end{array}$ & $\begin{array}{llll}13 / 4 & 15 / 4 & 17 / 4 & 19 / 4\end{array}$ & \begin{tabular}{|llll}
$13 / 4$ & $15 / 4$ & $17 / 4$ & $19 / 4$
\end{tabular} & $\begin{array}{llll}1 & 1 & 1 & 1\end{array}$ \\
\hline LD & 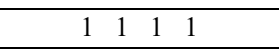 & $\begin{array}{lllll} & 1 & 1 & 1 & 1 \\
\end{array}$ & $\begin{array}{|lllll|} & 1 & 1 & 1 & 1 \\
\end{array}$ & $\begin{array}{llll}1 & 1 & 1 & 1 \\
\end{array}$ \\
\hline $\mathbf{A} \sigma \sigma$ & $\begin{array}{llll}7 & 7 & 29 & 313\end{array}$ & $\begin{array}{llll}7 & 67 & 9 & 336\end{array}$ & $\begin{array}{llll}31 & 94 & 164 & 213\end{array}$ & $\begin{array}{llll}19 & 43 & 183 & 251\end{array}$ \\
\hline Agg & $\begin{array}{llll}\overline{19} & \overline{8} & \overline{14} & \overline{68}\end{array}$ & $\begin{array}{llll}\overline{23} & \overline{90} & \overline{5} & \overline{83}\end{array}$ & $\overline{68} \quad \overline{93} \quad \overline{71} \quad \overline{43}$ & $\overline{36} \quad \overline{37} \quad \overline{70} \quad \overline{45}$ \\
\hline
\end{tabular}


Table L. Fuzzified Pugh Matrix for Life Cycle Cost using all design concept as baseline

\begin{tabular}{|c|c|c|c|c|}
\hline \multirow{2}{*}{\begin{tabular}{|c|} 
Sub \\
features \\
of LC
\end{tabular}} & \multicolumn{4}{|c|}{ Design Concepts } \\
\hline & Concept 1 & Concept 2 & Concept 3 & Concept 4 \\
\hline \begin{tabular}{|l|} 
DA \\
\end{tabular} & \begin{tabular}{llll|}
1 & 1 & 1 & 1
\end{tabular} & \begin{tabular}{llll|}
$5 / 2$ & 3 & $7 / 2$ & 4
\end{tabular} & $\begin{array}{llll}1 & 3 / 2 & 2 & 5 / 2\end{array}$ & $\begin{array}{llll}7 / 4 & 9 / 4 & 11 / 4 & 13 / 4\end{array}$ \\
\hline SR & $\begin{array}{llll} & 1 & 1 & 1\end{array}$ & $\begin{array}{llll}7 / 4 & 9 / 4 & 11 / 4 & 13 / 4\end{array}$ & $\begin{array}{llll}5 / 2 & 3 & 7 / 2 & 4\end{array}$ & $\begin{array}{llll}5 / 2 & 3 & 7 / 2 & 4\end{array}$ \\
\hline $\mathrm{RC}$ & \begin{tabular}{llll|}
1 & 1 & 1 & 1
\end{tabular} & $\begin{array}{llll}1 & 3 / 2 & 2 & 5 / 2\end{array}$ & $\begin{array}{llll}5 / 2 & 3 & 7 / 2 & 4 \\
\end{array}$ & $\begin{array}{llll}13 / 4 & 15 / 4 & 17 / 4 & 19 / 4\end{array}$ \\
\hline $\mathrm{OC}$ & \begin{tabular}{llll|}
1 & 1 & 1 & 1
\end{tabular} & $\begin{array}{llll}1 & 3 / 2 & 2 & 5 / 2\end{array}$ & $\begin{array}{|cccc|}7 / 4 & 9 / 4 & 11 / 4 & 13 / 4 \\
\end{array}$ & $\begin{array}{|llll|}5 / 2 & 3 & 7 / 2 & 4 \\
\end{array}$ \\
\hline $\mathrm{SC}$ & $\begin{array}{lll}1 & 1 & 1\end{array}$ & $\begin{array}{llll} & 1 & 1 & 1\end{array}$ & $\begin{array}{llllll} & 1 & 1 & 1 & 1\end{array}$ & $\begin{array}{llll}1 & 1 & 1 & 1\end{array}$ \\
\hline$\overline{D A}$ & \begin{tabular}{llll|}
$5 / 2$ & 3 & $7 / 2$ & 4
\end{tabular} & $\begin{array}{llll}1 & 1 & 1 & 1\end{array}$ & $\begin{array}{llll}1 & 3 / 2 & 2 & 5 / 2\end{array}$ & $\begin{array}{llll}1 & 3 / 2 & 2 & 5 / 2\end{array}$ \\
\hline SR & $\begin{array}{llll}7 / 4 & 9 / 4 & 11 / 4 & 13 / 4\end{array}$ & $\begin{array}{llll}1 & 1 & 1 & 1\end{array}$ & $\begin{array}{llll}1 & 1 & 1 & 1 \\
\end{array}$ & $\begin{array}{llll}1 & 3 / 2 & 2 & 5 / 2\end{array}$ \\
\hline $\mathrm{RC}$ & $\begin{array}{llll}1 & 3 / 2 & 2 & 5 / 2\end{array}$ & $\begin{array}{llll} & 1 & 1 & 1\end{array}$ & $\begin{array}{llll}7 / 4 & 9 / 4 & 11 / 4 & 13 / 4\end{array}$ & $\begin{array}{llll}1 & 3 / 2 & 2 & 5 / 2\end{array}$ \\
\hline $\mathrm{OC}$ & $\begin{array}{llll}7 / 4 & 9 / 4 & 11 / 4 & 13 / 4\end{array}$ & $\begin{array}{llll}1 & 1 & 1 & 1\end{array}$ & $\begin{array}{llll}1 & 3 / 2 & 2 & 5 / 2\end{array}$ & $\begin{array}{llll}1 & 3 / 2 & 2 & 5 / 2\end{array}$ \\
\hline $\mathrm{SC}$ & $\begin{array}{llllll} & 1 & 1 & 1 & 1\end{array}$ & $\begin{array}{llll}1 & 1 & 1 & 1\end{array}$ & $\begin{array}{llll}1 & 1 & 1 & 1\end{array}$ & $\begin{array}{llll}1 & 1 & 1 & 1\end{array}$ \\
\hline$\overline{\mathrm{DA}}$ & $13 / 4 \quad 15 / 4 \quad 17 / 4 \quad 19 / 4$ & $\begin{array}{llll}5 / 2 & 3 & 7 / 2 & 4\end{array}$ & $\begin{array}{llll}1 & 1 & 1 & 1\end{array}$ & $\begin{array}{llll}5 / 2 & 3 & 7 / 2 & 4 \\
\end{array}$ \\
\hline SR & $\begin{array}{llll}7 / 4 & 9 / 4 & 11 / 4 & 13 / 4\end{array}$ & $\begin{array}{llll}7 / 4 & 9 / 4 & 11 / 4 & 13 / 4\end{array}$ & $\begin{array}{llll}1 & 1 & 1 & 1\end{array}$ & $\begin{array}{llll}1 & 1 & 1 & 1\end{array}$ \\
\hline $\mathrm{RC}$ & $\begin{array}{lllll}1 & 1 & 1 & 1\end{array}$ & $\begin{array}{llll}1 & 3 / 2 & 2 & 5 / 2 \\
\end{array}$ & \begin{tabular}{llll|}
1 & 1 & 1 & 1
\end{tabular} & \begin{tabular}{llll|}
$5 / 2$ & 3 & $7 / 2$ & 4 \\
\end{tabular} \\
\hline $\mathrm{OC}$ & \begin{tabular}{llll|}
$5 / 2$ & 3 & $7 / 2$ & 4 \\
\end{tabular} & \begin{tabular}{llll|}
$5 / 2$ & 3 & $7 / 2$ & 4
\end{tabular} & \begin{tabular}{llll|}
1 & 1 & 1 & 1
\end{tabular} & \begin{tabular}{llll|}
$5 / 2$ & 3 & $7 / 2$ & 4
\end{tabular} \\
\hline $\mathrm{SC}$ & $\begin{array}{llll}1 & 1 & 1 & 1\end{array}$ & $\begin{array}{llll}1 & 1 & 1 & 1\end{array}$ & $\begin{array}{llll} & 1 & 1 & 1\end{array}$ & $\begin{array}{llll}1 & 1 & 1 & 1\end{array}$ \\
\hline DA & $\begin{array}{llll}7 / 4 & 9 / 4 & 11 / 4 & 13 / 4\end{array}$ & $\begin{array}{llll}7 / 4 & 9 / 4 & 11 / 4 & 13 / 4\end{array}$ & $\begin{array}{llll}1 & 3 / 2 & 2 & 5 / 2\end{array}$ & $\begin{array}{llll}1 & 1 & 1 & 1\end{array}$ \\
\hline SR & $\begin{array}{llll}5 / 2 & 3 & 7 / 2 & 4 \\
\end{array}$ & $\begin{array}{llll}3 / 4 & 15 / 4 & 17 / 4 & 19 / 4\end{array}$ & $13 / 4 \quad 15 / 4 \quad 17 / 4 \quad 19 / 4$ & \begin{tabular}{llll|}
1 & 1 & 1 & 1
\end{tabular} \\
\hline $\mathrm{RC}$ & $13 / 4 \quad 15 / 4 \quad 17 / 4 \quad 19 / 4$ & $13 / 4 \quad 15 / 4 \quad 17 / 4 \quad 19 / 4$ & $\begin{array}{|llll|}5 / 2 & 3 & 7 / 2 & 4\end{array}$ & $\begin{array}{llll}1 & 1 & 1 & 1\end{array}$ \\
\hline $\mathrm{OC}$ & $\begin{array}{llll}13 / 4 & 15 / 4 & 17 / 4 & 19 / 4\end{array}$ & $\begin{array}{llll}13 / 4 & 15 / 4 & 17 / 4 & 19 / 4\end{array}$ & $\begin{array}{llll}5 / 2 & 3 & 7 / 2 & 4\end{array}$ & $\begin{array}{llll}1 & 1 & 1 & 1\end{array}$ \\
\hline $\mathrm{SC}$ & $\begin{array}{lllll}1 & 1 & 1 & 1 \\
\end{array}$ & $\begin{array}{lllll}1 & 1 & 1 & 1 \\
\end{array}$ & $\begin{array}{llll}1 & 1 & 1 & 1 \\
\end{array}$ & \begin{tabular}{llll|}
1 & 1 & 1 & 1 \\
\end{tabular} \\
\hline $\mathbf{A} \sigma \alpha$ & $23 \quad 3 \quad 4$ & $\begin{array}{llll}3 & 37 & 12 & 200\end{array}$ & $\begin{array}{llll}1 & 29 & 33 & 254\end{array}$ & $\begin{array}{llll}21 & 41 & 56 & 106\end{array}$ \\
\hline Agg & $\overline{90} \overline{5} \quad \overline{3}$ & $\overline{16} \overline{79} \quad \overline{11} \overline{79}$ & 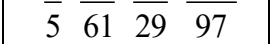 & 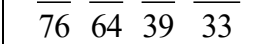 \\
\hline
\end{tabular}


Table M. Fuzzified Pugh Matrix for Maintainability using all design concept as baseline

\begin{tabular}{|c|c|c|c|c|}
\hline \multirow{2}{*}{$\begin{array}{c}\text { Sub } \\
\text { features } \\
\text { of } \mathrm{MN}\end{array}$} & \multicolumn{4}{|c|}{ Design Concepts } \\
\hline & Concept 1 & Concept 2 & Concept 3 & Concept 4 \\
\hline $\mathrm{RM}$ & $\begin{array}{llll}1 & 1 & 1 & 1\end{array}$ & $\begin{array}{llll}1 & 1 & 1 & 1\end{array}$ & $\begin{array}{llll}1 & 1 & 1 & 1\end{array}$ & $\begin{array}{llll}1 & 1 & 1 & 1\end{array}$ \\
\hline DM & $\begin{array}{llll}1 & 1 & 1 & 1\end{array}$ & $\begin{array}{llll}5 / 2 & 3 & 7 / 2 & 4\end{array}$ & $\begin{array}{llll}5 / 2 & 3 & 7 / 2 & 4\end{array}$ & $\begin{array}{llll}7 / 4 & 9 / 4 & 11 / 4 & 13 / 4\end{array}$ \\
\hline $\mathrm{MC}$ & \begin{tabular}{llll|}
1 & 1 & 1 & 1 \\
\end{tabular} & $13 / 4 \quad 15 / 4 \quad 17 / 4 \quad 19 / 4$ & $\begin{array}{llll}5 / 2 & 3 & 7 / 2 & 4 \\
\end{array}$ & $13 / 4 \quad 15 / 4 \quad 17 / 4 \quad 19 / 4$ \\
\hline LP & \begin{tabular}{llll|}
1 & 1 & 1 & 1 \\
\end{tabular} & $13 / 4 \quad 15 / 4 \quad 17 / 4 \quad 19 / 4$ & $\begin{array}{llll}3 / 4 & 15 / 4 & 17 / 4 & 19 / 4\end{array}$ & $\begin{array}{llll}1 & 3 / 2 & 2 & 5 / 2\end{array}$ \\
\hline MF & $\begin{array}{llll}1 & 1 & 1 & 1\end{array}$ & $\begin{array}{llll}5 / 2 & 3 & 7 / 2 & 4\end{array}$ & $\begin{array}{llll}5 / 2 & 3 & 7 / 2 & 4\end{array}$ & $\begin{array}{llll}7 / 4 & 9 / 4 & 11 / 4 & 13 / 4\end{array}$ \\
\hline MS & $\begin{array}{lll}1 & 1 & 1\end{array}$ & $\begin{array}{llll}1 & 1 & 1 & 1 \\
\end{array}$ & $\begin{array}{llll}1 & 1 & 1 & 1 \\
\end{array}$ & 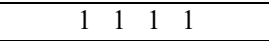 \\
\hline RM & $\begin{array}{llll}1 & 1 & 1 & 1\end{array}$ & $\begin{array}{llll}1 & 1 & 1 & 1\end{array}$ & $\begin{array}{llll}1 & 1 & 1 & 1\end{array}$ & $\begin{array}{lll}1 & 1 & 1\end{array}$ \\
\hline DM & $\begin{array}{llll}7 / 4 & 9 / 4 & 11 / 4 & 13 / 4\end{array}$ & $\begin{array}{llll}1 & 1 & 1 & 1\end{array}$ & $\begin{array}{llll}1 & 1 & 1 & 1\end{array}$ & $\begin{array}{llll}1 & 3 / 2 & 2 & 5 / 2\end{array}$ \\
\hline $\mathrm{MC}$ & $\begin{array}{llll}1 & 3 / 2 & 2 & 5 / 2\end{array}$ & $\begin{array}{llll}1 & 1 & 1 & 1\end{array}$ & $\begin{array}{llll}7 / 4 & 9 / 4 & 11 / 4 & 13 / 4\end{array}$ & $\begin{array}{llll} & 1 & 1 & 1\end{array}$ \\
\hline LP & $\begin{array}{llll}1 & 3 / 2 & 2 & 5 / 2 \\
\end{array}$ & $\begin{array}{llll}1 & 1 & 1 & 1 \\
\end{array}$ & $\begin{array}{llll}1 & 1 & 1 & 1 \\
\end{array}$ & $\begin{array}{llll}1 & 3 / 2 & 2 & 5 / 2\end{array}$ \\
\hline MF & $\begin{array}{llll}7 / 4 & 9 / 4 & 11 / 4 & 13 / 4\end{array}$ & $\begin{array}{llll}1 & 1 & 1 & 1\end{array}$ & $\begin{array}{llll}1 & 1 & 1 & 1 \\
\end{array}$ & $\begin{array}{llll} & 3 / 2 & 2 & 5 / 2\end{array}$ \\
\hline MS & $\begin{array}{lllll} & 1 & 1 & 1 & 1 \\
\end{array}$ & $\begin{array}{llll}1 & 1 & 1 & 1\end{array}$ & $\begin{array}{lll}1 & 1 & 1\end{array}$ & $\begin{array}{llll} & 1 & 1 & 1 \\
\end{array}$ \\
\hline RM & $\begin{array}{llll}1 & 1 & 1 & 1 \\
\end{array}$ & $\begin{array}{llll}1 & 1 & 1 & 1 \\
\end{array}$ & $\begin{array}{lll}1 & 1 & 1\end{array}$ & $\begin{array}{llll}1 & 1 & 1 & 1 \\
\end{array}$ \\
\hline $\mathrm{DM}$ & $\begin{array}{llll}7 / 4 & 9 / 4 & 11 / 4 & 13 / 4 \\
\end{array}$ & \begin{tabular}{llll|}
1 & 1 & 1 & 1 \\
\end{tabular} & \begin{tabular}{llll|}
1 & 1 & 1 & 1 \\
\end{tabular} & $\begin{array}{llll}1 & 3 / 2 & 2 & 5 / 2 \\
\end{array}$ \\
\hline $\mathrm{MC}$ & $\begin{array}{llll}7 / 4 & 9 / 4 & 11 / 4 & 13 / 4 \\
\end{array}$ & $\begin{array}{llll}5 / 2 & 3 & 7 / 2 & 4 \\
\end{array}$ & $\begin{array}{lll}1 & 1 & 1 \\
\end{array}$ & $\begin{array}{llll}5 / 2 & 3 & 7 / 2 & 4 \\
\end{array}$ \\
\hline LP & $\begin{array}{llll}1 & 3 / 2 & 2 & 5 / 2\end{array}$ & $\begin{array}{llll} & 1 & 1 & 1\end{array}$ & $\begin{array}{lll}1 & 1 & 1\end{array}$ & $\begin{array}{llll}1 & 3 / 2 & 2 & 5 / 2\end{array}$ \\
\hline MF & $\begin{array}{llll}7 / 4 & 9 / 4 & 11 / 4 & 13 / 4\end{array}$ & $\begin{array}{llll}1 & 1 & 1 & 1\end{array}$ & $\begin{array}{llll}1 & 1 & 1 & 1\end{array}$ & $\begin{array}{llll}1 & 3 / 2 & 2 & 5 / 2\end{array}$ \\
\hline MS & 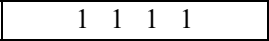 & $\begin{array}{llll}1 & 1 & 1 & 1 \\
\end{array}$ & \begin{tabular}{llll|}
1 & 1 & 1 & 1 \\
\end{tabular} & $\begin{array}{llll} & 1 & 1 & 1 \\
\end{array}$ \\
\hline RM & $\begin{array}{llll}1 & 1 & 1 & 1 \\
\end{array}$ & $\begin{array}{llll}1 & 1 & 1 & 1 \\
\end{array}$ & $\begin{array}{llll}1 & 1 & 1 & 1 \\
\end{array}$ & $\begin{array}{llll}1 & 1 & 1 & 1\end{array}$ \\
\hline $\mathrm{DM}$ & $\begin{array}{llll}5 / 2 & 3 & 7 / 2 & 4 \\
\end{array}$ & $13 / 4 \quad 15 / 4 \quad 17 / 4 \quad 19 / 4$ & $13 / 4 \quad 15 / 4 \quad 17 / 4 \quad 19 / 4$ & \begin{tabular}{llll|}
1 & 1 & 1 & 1 \\
\end{tabular} \\
\hline $\mathrm{MC}$ & $\begin{array}{llll}1 & 3 / 2 & 2 & 5 / 2 \\
\end{array}$ & $\begin{array}{llllll} & 1 & 1 & 1 & 1 \\
\end{array}$ & $\begin{array}{llll}7 / 4 & 9 / 4 & 11 / 4 & 13 / 4\end{array}$ & $\begin{array}{lll}1 & 1 & 1\end{array}$ \\
\hline LP & $13 / 4 \quad 15 / 4 \quad 17 / 4 \quad 19 / 4$ & $13 / 4 \quad 15 / 4 \quad 17 / 4 \quad 19 / 4$ & $13 / 4 \quad 15 / 4 \quad 17 / 4 \quad 19 / 4$ & $\begin{array}{ll}1 & 1 \\
\end{array}$ \\
\hline MF & $\begin{array}{llll}5 / 2 & 3 & 7 / 2 & 4 \\
\end{array}$ & $13 / 4 \quad 15 / 4 \quad 17 / 4 \quad 19 / 4$ & $13 / 4 \quad 15 / 4 \quad 17 / 4 \quad 19 / 4$ & $\begin{array}{lll}1 & 1 & 1 \\
\end{array}$ \\
\hline MS & $\begin{array}{llll}1 & 1 & 1 & 1 \\
\end{array}$ & $\begin{array}{llllll} & 1 & 1 & 1 & 1 \\
\end{array}$ & $\begin{array}{lllll}1 & 1 & 1 & 1 \\
\end{array}$ & \begin{tabular}{llll|}
1 & 1 & 1 & 1 \\
\end{tabular} \\
\hline Agg & $\begin{array}{llll}10 & 14 & 83 & 21\end{array}$ & $11 \leq \underline{57} \quad \underline{100}$ & $14 \quad 11 \quad 11 \quad 265$ & $13 \quad 16 \quad 21 \quad 73$ \\
\hline & $\begin{array}{llll}51 & 29 & 74 & 8\end{array}$ & $\begin{array}{llll}45 & 9 & 47 & 37\end{array}$ & $\begin{array}{llll}59 & 20 & 9 & 96\end{array}$ & $\begin{array}{llll}69 & 35 & 20 & 30\end{array}$ \\
\hline
\end{tabular}


Table N. Fuzzified Pugh Matrix for Reliability using all design concept as baseline

\begin{tabular}{|c|c|c|c|c|}
\hline \multirow{2}{*}{\begin{tabular}{|c|}
$\begin{array}{c}\text { Sub } \\
\text { features } \\
\text { of RE }\end{array}$ \\
\end{tabular}} & \multicolumn{4}{|c|}{ Design Concepts } \\
\hline & Concept 1 & Concept 2 & Concept 3 & Concept 4 \\
\hline \begin{tabular}{|l|}
$\mathrm{RF}$ \\
\end{tabular} & \begin{tabular}{llll|}
1 & 1 & 1 & 1
\end{tabular} & \begin{tabular}{llll|}
$5 / 2$ & 3 & $7 / 2$ & 4
\end{tabular} & \begin{tabular}{llll|}
$7 / 4$ & $9 / 4$ & $11 / 4$ & $13 / 4$
\end{tabular} & $\begin{array}{llll}1 & 3 / 2 & 2 & 5 / 2\end{array}$ \\
\hline UL & $\begin{array}{llll} & 1 & 1 & 1\end{array}$ & $\begin{array}{llll}5 / 2 & 3 & 7 / 2 & 4\end{array}$ & $\begin{array}{llll}5 / 2 & 3 & 7 / 2 & 4\end{array}$ & $\begin{array}{llll}1 & 3 / 2 & 2 & 5 / 2\end{array}$ \\
\hline $\mathrm{DC}$ & \begin{tabular}{llll|}
1 & 1 & 1 & 1
\end{tabular} & $\begin{array}{|llll|}7 / 4 & 9 / 4 & 11 / 4 & 13 / 4\end{array}$ & \begin{tabular}{llll|}
$7 / 4$ & $9 / 4$ & $11 / 4$ & $13 / 4$
\end{tabular} & $\begin{array}{llll}5 / 2 & 3 & 7 / 2 & 4\end{array}$ \\
\hline $\mathrm{RD}$ & \begin{tabular}{llll|}
1 & 1 & 1 & 1
\end{tabular} & $\begin{array}{llllll} & 1 & 1 & 1 & 1\end{array}$ & $\begin{array}{llllll} & 1 & 1 & 1 & 1\end{array}$ & $\begin{array}{llll}1 & 1 & 1 & 1 \\
\end{array}$ \\
\hline RS & $\begin{array}{llll}1 & 1 & 1 & 1\end{array}$ & $\begin{array}{llll}13 / 4 & 15 / 4 & 17 / 4 & 19 / 4\end{array}$ & $\begin{array}{llll}5 / 2 & 3 & 7 / 2 & 4\end{array}$ & $\begin{array}{llll}7 / 4 & 9 / 4 & 11 / 4 & 13 / 4\end{array}$ \\
\hline $\mathrm{RF}$ & $\begin{array}{llll}7 / 4 & 9 / 4 & 11 / 4 & 13 / 4\end{array}$ & $\begin{array}{llllll} & 1 & 1 & 1 & 1 \\
\end{array}$ & $\begin{array}{llll}1 & 3 / 2 & 2 & 5 / 2\end{array}$ & $\begin{array}{llll}1 & 3 / 2 & 2 & 5 / 2\end{array}$ \\
\hline UL & \begin{tabular}{llll|}
$7 / 4$ & $9 / 4$ & $11 / 4$ & $13 / 4$
\end{tabular} & $\begin{array}{llll}1 & 1 & 1 & 1\end{array}$ & $\begin{array}{llll}1 & 1 & 1 & 1\end{array}$ & $\begin{array}{llll}1 & 3 / 2 & 2 & 5 / 2\end{array}$ \\
\hline $\mathrm{DC}$ & $\begin{array}{llll}5 / 2 & 3 & 7 / 2 & 4\end{array}$ & $\begin{array}{llll}1 & 1 & 1 & 1\end{array}$ & $\begin{array}{llll}1 & 1 & 1 & 1\end{array}$ & $\begin{array}{llll}5 / 2 & 3 & 7 / 2 & 4\end{array}$ \\
\hline $\mathrm{RD}$ & $\begin{array}{llll}1 & 1 & 1 & 1\end{array}$ & $\begin{array}{llll}1 & 1 & 1 & 1\end{array}$ & $\begin{array}{llll}1 & 1 & 1 & 1\end{array}$ & $\begin{array}{llll}1 & 1 & 1 & 1\end{array}$ \\
\hline RS & $\begin{array}{llll}1 & 3 / 2 & 2 & 5 / 2\end{array}$ & $\begin{array}{llll}1 & 1 & 1 & 1\end{array}$ & $\begin{array}{llll}7 / 4 & 9 / 4 & 11 / 4 & 13 / 4\end{array}$ & $\begin{array}{llll}1 & 3 / 2 & 2 & 5 / 2\end{array}$ \\
\hline $\mathrm{RF}$ & $\begin{array}{llll}5 / 2 & 3 & 7 / 2 & 4\end{array}$ & $13 / 4 \quad 15 / 4 \quad 17 / 4 \quad 19 / 4$ & $\begin{array}{llllll} & 1 & 1 & 1 & 1\end{array}$ & $\begin{array}{llll}7 / 4 & 9 / 4 & 11 / 4 & 13 / 4\end{array}$ \\
\hline UL & $\begin{array}{llll}7 / 4 & 9 / 4 & 11 / 4 & 13 / 4\end{array}$ & $\begin{array}{llllll} & 1 & 1 & 1 & 1\end{array}$ & $\begin{array}{llll}1 & 1 & 1 & 1\end{array}$ & $\begin{array}{llll}1 & 3 / 2 & 2 & 5 / 2\end{array}$ \\
\hline $\mathrm{DC}$ & $\begin{array}{llll}5 / 2 & 3 & 7 / 2 & 4\end{array}$ & \begin{tabular}{llll|}
1 & 1 & 1 & 1
\end{tabular} & \begin{tabular}{lll|}
1 & 1 & 1
\end{tabular} & \begin{tabular}{llll|}
$5 / 2$ & 3 & $7 / 2$ & 4 \\
\end{tabular} \\
\hline $\mathrm{RD}$ & $\begin{array}{llll}1 & 1 & 1 & 1\end{array}$ & $\begin{array}{llll}1 & 1 & 1 & 1\end{array}$ & \begin{tabular}{lll|}
1 & 1 & 1
\end{tabular} & $\begin{array}{llll}1 & 1 & 1 & 1\end{array}$ \\
\hline $\mathrm{RS}$ & $\begin{array}{llll}7 / 4 & 9 / 4 & 11 / 4 & 13 / 4 \\
\end{array}$ & $\begin{array}{llll}5 / 2 & 3 & 7 / 2 & 4 \\
\end{array}$ & $\begin{array}{llll}1 & 1 & 1 & 1 \\
\end{array}$ & $\begin{array}{llll}1 & 3 / 2 & 2 & 5 / 2\end{array}$ \\
\hline $\mathrm{RF}$ & $13 / 4 \quad 15 / 4 \quad 17 / 4 \quad 19 / 4$ & $\begin{array}{|llll|}13 / 4 & 15 / 4 & 17 / 4 & 19 / 4 \\
\end{array}$ & $\begin{array}{llll}5 / 2 & 3 & 7 / 2 & 4\end{array}$ & $\begin{array}{llll}1 & 1 & 1 & 1\end{array}$ \\
\hline$\overline{\mathrm{UL}}$ & $\begin{array}{llll}13 / 4 & 15 / 4 & 17 / 4 & 19 / 4\end{array}$ & $\begin{array}{|llll|}13 / 4 & 15 / 4 & 17 / 4 & 19 / 4 \\
\end{array}$ & $\begin{array}{llll}13 / 4 & 15 / 4 & 17 / 4 & 19 / 4\end{array}$ & \begin{tabular}{llll|}
1 & 1 & 1 & 1
\end{tabular} \\
\hline $\mathrm{DC}$ & $\begin{array}{llll}7 / 4 & 9 / 4 & 11 / 4 & 13 / 4\end{array}$ & $\begin{array}{llll} & 3 / 2 & 2 & 5 / 2\end{array}$ & $\begin{array}{llll}1 & 3 / 2 & 2 & 5 / 2\end{array}$ & $\begin{array}{llll}1 & 1 & 1 & 1\end{array}$ \\
\hline $\mathrm{RD}$ & $\begin{array}{llllll} & 1 & 1 & 1 & 1\end{array}$ & $\begin{array}{llll}1 & 1 & 1 & 1\end{array}$ & $\begin{array}{llll}1 & 1 & 1 & 1\end{array}$ & $\begin{array}{llll}1 & 1 & 1 & 1\end{array}$ \\
\hline RS & $\begin{array}{llll}5 / 2 & 3 & 7 / 2 & 4 \\
\end{array}$ & \begin{tabular}{llll|}
$13 / 4$ & $15 / 4$ & $17 / 4$ & $19 / 4$ \\
\end{tabular} & $\begin{array}{llll}13 / 4 & 15 / 4 & 17 / 4 & 19 / 4 \\
\end{array}$ & \begin{tabular}{llll|}
1 & 1 & 1 & 1 \\
\end{tabular} \\
\hline $\mathbf{A} \sigma \alpha$ & $\begin{array}{llll}10 & 52 & 40 & 205\end{array}$ & $\begin{array}{llll}11 & 32 & 55 & 238\end{array}$ & $\begin{array}{llll}1 & 17 & 30 & 148\end{array}$ & $\begin{array}{llll}11 & 22 & 49 & 157\end{array}$ \\
\hline Agg & $\begin{array}{llll}\overline{39} & \overline{85} & \overline{29} & \overline{66}\end{array}$ & 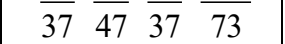 & $\overline{4} \overline{29} \overline{23} \overline{51}$ & 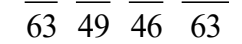 \\
\hline
\end{tabular}


Table O. Fuzzified Pugh Matrix for Flexibility using all design concept as baseline

\begin{tabular}{|c|c|c|c|c|}
\hline \multirow{2}{*}{$\begin{array}{c}\text { Sub } \\
\text { features } \\
\text { of FT }\end{array}$} & \multicolumn{4}{|c|}{ Design Concepts } \\
\hline & Concept 1 & Concept 2 & Concept 3 & Concept 4 \\
\hline $\mathrm{CP}$ & $\begin{array}{llll}1 & 1 & 1 & 1\end{array}$ & $\begin{array}{llll}1 & 3 / 2 & 2 & 5 / 2\end{array}$ & $\begin{array}{llll}7 / 4 & 9 / 4 & 11 / 4 & 13 / 4\end{array}$ & $\begin{array}{llll}5 / 2 & 3 & 7 / 2 & 4\end{array}$ \\
\hline SP & $\begin{array}{llll}1 & 1 & 1 & 1\end{array}$ & $\begin{array}{llll}13 / 4 & 15 / 4 & 17 / 4 & 19 / 4\end{array}$ & $\begin{array}{llll}5 / 2 & 3 & 7 / 2 & 4\end{array}$ & $\begin{array}{llll}5 / 2 & 3 & 7 / 2 & 4\end{array}$ \\
\hline SB & $\begin{array}{llll}1 & 1 & 1 & 1\end{array}$ & $\begin{array}{llll}5 / 2 & 3 & 7 / 2 & 4\end{array}$ & $\begin{array}{llll}7 / 4 & 9 / 4 & 11 / 4 & 13 / 4\end{array}$ & $\begin{array}{llll}1 & 1 & 1 & 1\end{array}$ \\
\hline $\mathrm{CU}$ & $\begin{array}{llll}1 & 1 & 1 & 1\end{array}$ & $\begin{array}{llll} & 1 & 1 & 1\end{array}$ & $\begin{array}{lllll} & 1 & 1 & 1 & 1\end{array}$ & $\begin{array}{llll}1 & 1 & 1 & 1\end{array}$ \\
\hline ML & $\begin{array}{llll}1 & 1 & 1 & 1\end{array}$ & $\begin{array}{llll}5 / 2 & 3 & 7 / 2 & 4\end{array}$ & $\begin{array}{llll}3 / 4 & 15 / 4 & 17 / 4 & 19 / 4\end{array}$ & $\begin{array}{llll}7 / 4 & 9 / 4 & 11 / 4 & 13 / 4\end{array}$ \\
\hline $\mathrm{CP}$ & $13 / 4 \quad 15 / 4 \quad 17 / 4 \quad 19 / 4$ & $\begin{array}{llll}1 & 1 & 1 & 1 \\
\end{array}$ & $\begin{array}{llll}5 / 2 & 3 & 7 / 2 & 4 \\
\end{array}$ & $13 / 4 \quad 15 / 4 \quad 17 / 4 \quad 19 / 4$ \\
\hline SP & $\begin{array}{llll}1 & 3 / 2 & 2 & 5 / 2\end{array}$ & $\begin{array}{llll}1 & 1 & 1 & 1\end{array}$ & $\begin{array}{llll}7 / 4 & 9 / 4 & 11 / 4 & 13 / 4\end{array}$ & $\begin{array}{|llll|}7 / 4 & 9 / 4 & 11 / 4 & 13 / 4 \\
\end{array}$ \\
\hline SB & $\begin{array}{llll}7 / 4 & 9 / 4 & 11 / 4 & 13 / 4\end{array}$ & $\begin{array}{llll}1 & 1 & 1 & 1\end{array}$ & $\begin{array}{llll}1 & 3 / 2 & 2 & 5 / 2\end{array}$ & $\begin{array}{llll}7 / 4 & 9 / 4 & 11 / 4 & 13 / 4\end{array}$ \\
\hline $\mathrm{CU}$ & $\begin{array}{llll}1 & 1 & 1 & 1\end{array}$ & $\begin{array}{llll}1 & 1 & 1 & 1\end{array}$ & $\begin{array}{llll} & 1 & 1 & 1\end{array}$ & $\begin{array}{llll}1 & 1 & 1 & 1\end{array}$ \\
\hline ML & $\begin{array}{llll}7 / 4 & 9 / 4 & 11 / 4 & 13 / 4\end{array}$ & $\begin{array}{llll}1 & 1 & 1 & 1\end{array}$ & $\begin{array}{llll}5 / 2 & 3 & 7 / 2 & 4\end{array}$ & $\begin{array}{llll}1 & 3 / 2 & 2 & 5 / 2\end{array}$ \\
\hline $\mathrm{CP}$ & $\begin{array}{llll}5 / 2 & 3 & 7 / 2 & 4 \\
\end{array}$ & $\begin{array}{llll}7 / 4 & 9 / 4 & 11 / 4 & 13 / 4\end{array}$ & $\begin{array}{llll}1 & 1 & 1 & 1\end{array}$ & $\begin{array}{llll}5 / 2 & 3 & 7 / 2 & 4\end{array}$ \\
\hline SP & $\begin{array}{llll}7 / 4 & 9 / 4 & 11 / 4 & 13 / 4\end{array}$ & $\begin{array}{llll}5 / 2 & 3 & 7 / 2 & 4\end{array}$ & $\begin{array}{llll}1 & 1 & 1 & 1\end{array}$ & 11 \\
\hline SB & $\begin{array}{llll}5 / 2 & 3 & 7 / 2 & 4\end{array}$ & $\begin{array}{llll}3 / 4 & 15 / 4 & 17 / 4 & 19 / 4\end{array}$ & $\begin{array}{llll}1 & 1 & 1 & 1 \\
\end{array}$ & $\begin{array}{llll}5 / 2 & 3 & 7 / 2 & 4 \\
\end{array}$ \\
\hline $\mathrm{CU}$ & $\begin{array}{llll}1 & 1 & 1 & 1 \\
\end{array}$ & $\begin{array}{lllll}1 & 1 & 1 & 1 \\
\end{array}$ & \begin{tabular}{llll|}
1 & 1 & 1 & 1 \\
\end{tabular} & $\begin{array}{llll}1 & 1 & 1 & 1\end{array}$ \\
\hline ML & $\begin{array}{llll}1 & 3 / 2 & 2 & 5 / 2\end{array}$ & $\begin{array}{llll}7 / 4 & 9 / 4 & 11 / 4 & 13 / 4\end{array}$ & $\begin{array}{ll}1 & 1\end{array}$ & $\begin{array}{llll}7 / 4 & 9 / 4 & 11 / 4 & 13 / 4\end{array}$ \\
\hline $\mathrm{CP}$ & $\begin{array}{llll}7 / 4 & 9 / 4 & 11 / 4 & 13 / 4\end{array}$ & $\begin{array}{llll}1 & 3 / 2 & 2 & 5 / 2\end{array}$ & $\begin{array}{llll}1 & 3 / 2 & 2 & 5 / 2\end{array}$ & $\begin{array}{llll}1 & 1 & 1 & 1 \\
\end{array}$ \\
\hline SP & $\begin{array}{llll}7 / 4 & 9 / 4 & 11 / 4 & 13 / 4\end{array}$ & $\begin{array}{llll}13 / 4 & 15 / 4 & 17 / 4 & 19 / 4\end{array}$ & $\begin{array}{llll}1 & 1 & 1 & 1\end{array}$ & $\begin{array}{ll}1 & 1\end{array}$ \\
\hline SB & $\begin{array}{llll}1 & 1 & 1 & 1\end{array}$ & $\begin{array}{llll}5 / 2 & 3 & 7 / 2 & 4\end{array}$ & $\begin{array}{llll}7 / 4 & 9 / 4 & 11 / 4 & 13 / 4\end{array}$ & $\begin{array}{ll}1 & 1\end{array}$ \\
\hline $\mathrm{CU}$ & $\begin{array}{llll}1 & 1 & 1 & 1 \\
\end{array}$ & $\begin{array}{llll}1 & 1 & 1 & 1 \\
\end{array}$ & $\begin{array}{llll}1 & 1 & 1 & 1 \\
\end{array}$ & \begin{tabular}{llll|}
1 & 1 & 1 & 1 \\
\end{tabular} \\
\hline ML & $\begin{array}{llll}5 / 2 & 3 & 7 / 2 & 4 \\
\end{array}$ & $\begin{array}{llll}13 / 4 & 15 / 4 & 17 / 4 & 19 / 4 \\
\end{array}$ & \begin{tabular}{llll|}
$13 / 4$ & $15 / 4$ & $17 / 4$ & $19 / 4$ \\
\end{tabular} & $\begin{array}{llll}1 & 1 & 1 & 1 \\
\end{array}$ \\
\hline A $\sigma g$ & $5 \quad 15 \quad 5 \quad 7$ & $4 \quad 7 \quad 11 \quad 72$ & $4 \quad 6 \quad 3 \quad 17$ & $7 \leq 31 \quad 8$ \\
\hline & $\overline{68} \quad \overline{94} \quad \overline{14} \quad \overline{8}$ & $\overline{43} \quad \overline{36} \quad \overline{26} \quad \overline{71}$ & $\begin{array}{llll}\overline{49} & \overline{35} & \overline{8} & \overline{19}\end{array}$ & $\overline{89} \overline{6} \quad \overline{84} \overline{9}$ \\
\hline
\end{tabular}


Table P. Fuzzified Pugh Matrix for Operation using all design concept as baseline

\begin{tabular}{|c|c|c|c|c|}
\hline \multirow{2}{*}{$\begin{array}{c}\begin{array}{c}\text { Sub } \\
\text { features } \\
\text { of OP }\end{array} \\
\end{array}$} & \multicolumn{4}{|c|}{ Design Concepts } \\
\hline & Concept 1 & Concept 2 & Concept 3 & Concept 4 \\
\hline & \begin{tabular}{llll|}
1 & 1 & 1 & 1
\end{tabular} & \begin{tabular}{llll|}
$5 / 2$ & 3 & $7 / 2$ & 4 \\
\end{tabular} & \begin{tabular}{llll|}
$5 / 2$ & 3 & $7 / 2$ & 4
\end{tabular} & 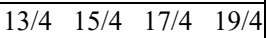 \\
\hline AS & $\begin{array}{llll} & 1 & 1 & 1\end{array}$ & $\begin{array}{llll}1 & 1 & 1 & 1\end{array}$ & $\begin{array}{llll}1 & 1 & 1 & 1\end{array}$ & $\begin{array}{llll}1 & 1 & 1 & 1\end{array}$ \\
\hline SL & \begin{tabular}{llll|}
1 & 1 & 1 & 1
\end{tabular} & $\begin{array}{llll}5 / 2 & 3 & 7 / 2 & 4 \\
\end{array}$ & $\begin{array}{llll}5 / 2 & 3 & 7 / 2 & 4 \\
\end{array}$ & $\begin{array}{llll}1 & 1 & 1 & 1\end{array}$ \\
\hline $\mathrm{EU}$ & $\begin{array}{llll}1 & 1 & 1 & 1 \\
\end{array}$ & $\begin{array}{llll}1 & 1 & 1 & 1 \\
\end{array}$ & $\begin{array}{llll}1 & 1 & 1 & 1 \\
\end{array}$ & $\begin{array}{llll}1 & 1 & 1 & 1 \\
\end{array}$ \\
\hline DT & $\begin{array}{llll}1 & 1 & 1 & 1\end{array}$ & $\begin{array}{llll}13 / 4 & 15 / 4 & 17 / 4 & 19 / 4\end{array}$ & $\begin{array}{llll}5 / 2 & 3 & 7 / 2 & 4\end{array}$ & $\begin{array}{llll}5 / 2 & 3 & 7 / 2 & 4\end{array}$ \\
\hline PM & $\begin{array}{llll}1 & 1 & 1 & 1\end{array}$ & $\begin{array}{llll}13 / 4 & 15 / 4 & 17 / 4 & 19 / 4\end{array}$ & $\begin{array}{llll}7 / 4 & 9 / 4 & 11 / 4 & 13 / 4\end{array}$ & $\begin{array}{llll}1 & 3 / 2 & 2 & 5 / 2\end{array}$ \\
\hline WF & $\begin{array}{llll}7 / 4 & 9 / 4 & 11 / 4 & 13 / 4\end{array}$ & $\begin{array}{lllll}1 & 1 & 1 & 1 & \end{array}$ & $\begin{array}{llll}1 & 1 & 1 & 1\end{array}$ & $\begin{array}{llll}5 / 2 & 3 & 7 / 2 & 4\end{array}$ \\
\hline AS & $\begin{array}{llllll} & 1 & 1 & 1 & 1\end{array}$ & $\begin{array}{llll}1 & 1 & 1 & 1\end{array}$ & $\begin{array}{lllll}1 & 1 & 1 & 1\end{array}$ & $\begin{array}{llll}1 & 1 & 1 & 1\end{array}$ \\
\hline SL & $\begin{array}{llll}7 / 4 & 9 / 4 & 11 / 4 & 13 / 4\end{array}$ & $\begin{array}{llll}1 & 1 & 1 & 1\end{array}$ & $\begin{array}{llll}1 & 1 & 1 & 1\end{array}$ & $\begin{array}{llll}7 / 4 & 9 / 4 & 11 / 4 & 13 / 4\end{array}$ \\
\hline EU & $\begin{array}{llllll} & 1 & 1 & 1 & 1\end{array}$ & $\begin{array}{llll}1 & 1 & 1 & 1\end{array}$ & $\begin{array}{llll}1 & 1 & 1 & 1\end{array}$ & $\begin{array}{llllll} & 1 & 1 & 1 & 1\end{array}$ \\
\hline DT & $\begin{array}{llll}1 & 3 / 2 & 2 & 5 / 2 \\
\end{array}$ & $\begin{array}{llll}1 & 1 & 1 & 1\end{array}$ & $\begin{array}{llll}7 / 4 & 9 / 4 & 11 / 4 & 13 / 4\end{array}$ & $\begin{array}{llll}1 & 3 / 2 & 2 & 5 / 2 \\
\end{array}$ \\
\hline PM & $\begin{array}{llll}1 & 3 / 2 & 2 & 5 / 2\end{array}$ & $\begin{array}{llll}1 & 1 & 1 & 1\end{array}$ & $\begin{array}{llll}1 & 3 / 2 & 2 & 5 / 2\end{array}$ & $\begin{array}{llll}1 & 3 / 2 & 2 & 5 / 2\end{array}$ \\
\hline WF & $\begin{array}{llll}7 / 4 & 9 / 4 & 11 / 4 & 13 / 4 \\
\end{array}$ & $\begin{array}{llll}1 & 1 & 1 & 1 \\
\end{array}$ & $\begin{array}{llll}1 & 1 & 1 & 1 \\
\end{array}$ & $\begin{array}{llll}5 / 2 & 3 & 7 / 2 & 4 \\
\end{array}$ \\
\hline AS & $\begin{array}{llllll} & 1 & 1 & 1 & 1\end{array}$ & $\begin{array}{llll}1 & 1 & 1 & 1\end{array}$ & $\begin{array}{llll}1 & 1 & 1 & 1\end{array}$ & $\begin{array}{llll}1 & 1 & 1 & 1\end{array}$ \\
\hline SL & $\begin{array}{llll}7 / 4 & 9 / 4 & 11 / 4 & 13 / 4\end{array}$ & $\begin{array}{llll}1 & 1 & 1 & 1\end{array}$ & $\begin{array}{llll}1 & 1 & 1 & 1 \\
\end{array}$ & $\begin{array}{llll}7 / 4 & 9 / 4 & 11 / 4 & 13 / 4\end{array}$ \\
\hline $\mathrm{EU}$ & $\begin{array}{lllll} & 1 & 1 & 1 & 1 \\
& & \end{array}$ & $\begin{array}{llll}1 & 1 & 1 & 1\end{array}$ & $\begin{array}{llll}1 & 1 & 1 & 1\end{array}$ & $\begin{array}{lllll} & 1 & 1 & 1 & 1 \\
\end{array}$ \\
\hline DT & $\begin{array}{llll}7 / 4 & 9 / 4 & 11 / 4 & 13 / 4 \\
\end{array}$ & $\begin{array}{lllll}5 / 2 & 3 & 7 / 2 & 4 \\
\end{array}$ & $\begin{array}{llll}1 & 1 & 1 & 1 \\
\end{array}$ & $\begin{array}{lllll}1 & 1 & 1 & 1 \\
\end{array}$ \\
\hline PM & $\begin{array}{llll}5 / 2 & 3 & 7 / 2 & 4\end{array}$ & $\begin{array}{llll}13 / 4 & 15 / 4 & 17 / 4 & 19 / 4\end{array}$ & $\begin{array}{llll}1 & 1 & 1 & 1\end{array}$ & $\begin{array}{llll}7 / 4 & 9 / 4 & 11 / 4 & 13 / 4\end{array}$ \\
\hline WF & $\begin{array}{llll}1 & 3 / 2 & 2 & 5 / 2\end{array}$ & $\begin{array}{llll}13 / 4 & 15 / 4 & 17 / 4 & 19 / 4\end{array}$ & $\begin{array}{|llll|}13 / 4 & 15 / 4 & 17 / 4 & 19 / 4 \\
\end{array}$ & $\begin{array}{|lllll|} & 1 & 1 & 1 & 1 \\
\end{array}$ \\
\hline AS & $\begin{array}{llll}1 & 1 & 1 & 1 \\
\end{array}$ & $\begin{array}{lllll} & 1 & 1 & 1 & 1 \\
\end{array}$ & 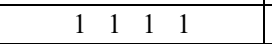 & $\begin{array}{llll}1 & 1 & 1 & 1\end{array}$ \\
\hline SL & \begin{tabular}{llll|}
1 & 1 & 1 & 1 \\
\end{tabular} & $\begin{array}{llll}5 / 2 & 3 & 7 / 2 & 4 \\
\end{array}$ & $\begin{array}{llll}5 / 2 & 3 & 7 / 2 & 4 \\
\end{array}$ & $\begin{array}{llll}1 & 1 & 1 & 1 \\
\end{array}$ \\
\hline EU & $\begin{array}{llll}1 & 1 & 1 & 1 \\
\end{array}$ & $\begin{array}{llll}1 & 1 & 1 & 1\end{array}$ & $\begin{array}{llll} & 1 & 1 & 1\end{array}$ & $\begin{array}{llll}1 & 1 & 1 & 1\end{array}$ \\
\hline DT & \begin{tabular}{llll|}
$7 / 4$ & $9 / 4$ & $11 / 4$ & $13 / 4$
\end{tabular} & $\begin{array}{llll}13 / 4 & 15 / 4 & 17 / 4 & 19 / 4\end{array}$ & $\begin{array}{llll}1 & 1 & 1 & 1\end{array}$ & $\begin{array}{llll}1 & 1 & 1 & 1\end{array}$ \\
\hline PM & $\begin{array}{llll}13 / 4 & 15 / 4 & 17 / 4 & 19 / 4 \\
\end{array}$ & $13 / 4 \quad 15 / 4 \quad 17 / 4 \quad 19 / 4$ & $\begin{array}{llll}5 / 2 & 3 & 7 / 2 & 4 \\
\end{array}$ & \begin{tabular}{llll|}
1 & 1 & 1 & 1 \\
\end{tabular} \\
\hline $\mathbf{A} \sigma \alpha$ & $\begin{array}{llll}13 & 53 & 35 & 87\end{array}$ & $\begin{array}{llll}1 & 76 & 97 & 209\end{array}$ & $\begin{array}{llll}2 & 49 & 153 & 356\end{array}$ & $\begin{array}{llll}23 & 25 & 74 & 37\end{array}$ \\
\hline Agg & $\overline{49} \quad \overline{79} \quad \overline{22} \quad \overline{23}$ & $\begin{array}{llll}3 & \overline{93} & \overline{51} & 47\end{array}$ & $\overline{7} \overline{69} \overline{92} \overline{91}$ & $\begin{array}{llll}84 & \overline{37} & \overline{47} & \overline{10}\end{array}$ \\
\hline
\end{tabular}

